Araştırma Makalesi - Research Article

\title{
Özel Sağlık Sigortası Talebini Etkileyen Faktörlerin İkili Lojistik Regresyon Yöntemiyle Analizi: İstanbul Örneği ${ }^{1}$
}

\section{Analysis of Factors Affecting Individuals' Private Health Insurance Demand with Binary Logistic Regression Method: The Case of İstanbul}

\section{Rüștü YAYAR* \\ (iD) 0000-0001-6758-4715}

\section{Ayșe Nur DAŞÇ I ${ }^{* *}$}

(iD) 0000-0003-2684-5661

\section{ÖZ}

Bireyler sigorta yaptırırken kendileri için en uygun sigorta poliçesini isterler. İnsanların sağlıklı yaşam istekleri, özel sağlık sigortası branşını ortaya çıkarmıştır. Türkiye'de özel sağlık sigortası branşının ülke ekonomisine katkısı önemlidir. Gelişmeye elverişli bir sektördür. Çalışmanın amacı bireylerin özel sağlık sigortası tercihini etkileyen faktörlerin belirlenmesidir. Araştırmanın ana kütlesi İstanbul ilinin 13 farklı bölgesinde yaşam standartları birbirlerinden farklı, 45 yaş üstü bireylerdir. Veriler yüz yüze görüşme tekniği ile 383 bireyden elde edilmiştir. Verilerin analizinde ikili lojistik regresyon yöntemi tercih edilmiştir. Karaciğer hastalı̆̆ 1 , beyin damar hastalığ 1 , doktorun yapmış olduğu uyarıları dikkate alma, aylık ortalama gelir, servet durumu ve eğitim düzeyi değişkenleri özel sağlık sigortası tercihini pozitif yönde etkilerken, sağlıklı besinler tüketmeye çalışma ve yaş değişkenleri negatif yönde etkilemektedir.

Anahtar Sözcükler: Sigorta, özel sağlık sigortas1, lojistik regresyon, İstanbul
Sosyal Güvenlik Dergisi / Journal of Social Security Cilt: 10 Say1: 1 Y1l: 2020 /Volume: 10 Issue: 1 Year: 2020 Sayfa Aralığı: 19-40/ Pages: 19-40

OI: $10.32331 /$ sgd.752099
Individuals want the most appropriate insurance policy for them when taking out insurance. The desire of people to live the healthy life has revealed the private health insurance branch. Private health insurance in Turkey has made significant contributions to the industry of the national economy. It is a sector suitable for development. The aim of this study was to determine the factors affecting private health insurance preference of individuals. The main population of the study is individuals over 45 years of age with different living standards in 13 different regions of Istanbul. Data were obtained from 383 individuals by face to face interview technique. In the analysis of the data, binary logistic regression method was preferred. The variables liver disease, cerebrovascular disease, taking into account the doctor's warnings, monthly average income, wealth status and education level positively affect the preference of private health insurance, while trying to consume healthy foods and age variables negatively affect.

Keywords: Insurance, private health insurance, logistic regression, İstanbul

Önerilen atıf şekli: Yayar, R. ve Daşcı, A. N. (2020). Özel Sağlık Sigortası Talebini Etkileyen Faktörlerin İkili Lojistik Regresyon Yöntemiyle Analizi: İstanbul Örneği. Sosyal Güvenlik Dergisi (Journal of Social Security). 10(1). 19-40.

\footnotetext{
* Prof. Dr., Tokat Gaziosmanpaşa Üniversitesi, İktisadi ve İdari Bilimler Fakültesi, İktisat Bölümü, rustu.yayar@gop.edu.tr

** Bilim Uzmanı, Tokat Gaziosmanpaşa Üniversitesi, Sosyal Bilimler Enstitüsü, İktisat Anabilim Dalı, aysenuraslan.economics@gmail.com

1 Bu çalışma, Tokat Gaziosmanpaşa Üniversitesi Sosyal Bilimler Enstitüsü’nün 31.08.2018 tarihinde kabul ettiği Yüksek Lisans tezinden türetilmiştir.
} 


\section{GİRIŞ}

Piyasa ekonomisi, arz ve talep güçlerinin serbest hareketine, fiyat mekanizmasının dış müdahalelerden mümkün olduğunca bağımsız işlemesine ve iktisadi karar birimlerinin tüketim, üretim ve yatırım kararlarını kendi özgür iradeleriyle serbestçe almalarına dayalı bir sistemdir. Piyasa ekonomisinde neyin üretileceğini, hangi fiyattan piyasaya arz edileceğini ve gelir dağılımının nasıl gerçekleşeceğini fiyat mekanizması belirler.

Sigorta kavramı, kişilerin yaşamlarının herhangi bir anında karşılaşabilecekleri zarar ve giderlere neden olan olayların finansal sonuçlarından kendilerini korumak için önceden önlem alma ihtiyacından doğmaktadır.

Kişilerin yaşları ilerledikçe hastalanma oranları da artmaktadır. Bu kişiler sigorta ile kendilerini güvence altına almak istemektedirler. Bireyler sigorta yaptırırken kendileri için en uygun sigorta poliçesini bulmaya kararlıdırlar. Fakat asimetrik bilgi probleminin varlığını ortadan kaldırmadan bunun olması pek mümkün gözükmemektedir. Sigorta yaptıran kişilerde sigorta yapan sigorta şirketleri de asimetrik bilginin her iki taraf içinde bir risk unsuru olduğunun farkındadır.

$\mathrm{Bu}$ çalışmada sigorta yaptıran kişilerin sigorta yaptırırken ne gibi detaylar aradıklarını belirlediğinden bölgede veya ülkede sigorta şirketlerini yönlendirmeye katkı sağlayacağı hedeflenmektedir. Sigorta şirketleri de kişilerin sigorta yaptırırken ne gibi unsurları göz önünde bulundurduğunu bildiğinde kendileri için daha karlı olan vizyonlar oluşturabilirler. Sigorta yaptıran kişiler açısından çalışmanın önemi ise sigorta yaptırırken aradıkları kıstasları bulabilmek ve gelişmiş bir hizmet anlayışı ile sigortadan faydalanmaları hedeflenmesidir.

Bu çalışma üç bölümden oluşacaktır. İlk bölümde asimetrik bilgi kavramı, ikinci bölüm de ise sigorta kavramı, son bölümde ise İstanbul ili bireylerin Özel Sağlık Sigortası Tercihini Etkileyen Faktörler ekonometrik olarak ortaya konulacaktır.

\section{I- SİGORTA VE SİGORTACILIĞIN TEMEL ISSLEVLERİ}

\section{A- Sigorta Kavramı ve Temel Özellikleri}

Sigorta kavramı, kişilerin yaşamlarının herhangi bir anında karşılaşabilecekleri maddi manevi zarara neden olan olaylardan kendilerini korumak için önceden önlem alma ihtiyacından ortaya çıkmaktadır. İnsanlar zorlu yaşam koşullarına karşı göstermiş oldukları direncin bir noktaya kadar sürebildiğini bunun yanı sıra daha farklı önlemler almaları gerektiğini anladıklarında sigorta işlev kazanmıştır (Uğur, 2004: 4). Sigortanın temel özellikleri; aynı tehlikeye maruz bir grubun bulunması, tesadüfi hasar tahmin edilebilir ve hesaplanabilir olduğu şeklindedir.

\section{i) Aynı Tehlikeye Maruz Grup}

Sigorta, çok sayıda kişi veya kuruma güvence hizmeti sunmak amacıyla geliştirilmiştir. Burada amaç, aynı tehlikenin tehdidi altında bulunan kişi ve kurumları bir araya getirmek ve bu sayede riski, grubun her üyesi için taşınabilir hale getirmektir. Bu anlamda, herhangi bir tehlike ile karşılaşıldığında karşılıklı olarak birbirlerini destekleme sorumluluğunda bulunan çok sayıda grup üyesinden bahsedilir. Bu gruplar, sigortanın öngördüğü, aynı tehlikenin tehdidi altında olan kişiler veya kurumların oluşturduğu gruplardan meydana gelir (Asunakutlu, 1997: 17). 


\section{ii) Tesadüfi Hasar}

Sigortanın en temel özelliği, teminat altına aldığı riskin gelecek dönemde gerçekleşme ihtimalinin olmasıdır. Geçmişte gerçekleşmiş veya gelecek dönemde gerçekleşme ihtimali olmayan riskler, sigorta kavramı içine alınmaz. Bundan dolayıdır ki sigortaya konu olacak riskin gerçekleşme ihtimalinin olması gerekmektedir. Gerçekleşen risk ise tesadüfi olmalı ve riski oluşturan tehlike beklenmedik bir zamanda ani ve harici olarak ortaya çıkabilme özelliğine sahip olmalıdır. Kasten ya da bilerek oluşan hasarların karşılanması için sigortacı sorumlu değildir (Bölükbaşı ve Pamukçu, 2009: 26).

\section{iii) Tahmin Edilebilir ve Hesaplanabilir Olma}

Hasarın oluşması halinde sigortalının hasarını gidermesi için hasarın tahmin edilebilir ve hesaplanabilecek düzeyde olması gerekir. Hesaplama, bilirlik olayların istatistiki açıdan incelenmesini sağlar. Bu durum prim oranlarının, hasar oranlarının ve hasar maliyetinin belirlenmesi için zorunludur (Duman, 1983: 15).

\section{B- Hayat Sigortası ve Türleri}

Hayat sigortası, insanın yaşama ihtimallerine bağlı bir sigorta türüdür. Eğer sigorta, ölüm ihtimaline göre yapılıyorsa, bu sigortaya hayat sigortası, yaşam ihtimaline göre yapılıyorsa, bu sigortaya ise anüite sigorta denir.

Hayat sigortasının temel amacı; sigortalıya, yaşlılığında sıkıntıya düşmeden hayatını sürdürme olanağını sağlamak, ölümü ya da sakat kalması halinde bakmakta olduğu, geride kalan aile bireylerine aynı faydayı sağlamaktır (Osmançavuşoğlu, 1999: 20).

Hayat sigortalarında risk, belirli bazı olayların meydana gelmesi ile kişisel gelirin durması veya tamamen ortadan kalkması şeklinde olmaktadır. Bu riski meydana getiren olaylar kaza ve hastalık, işsizlik, yaşlılık ve ölüm halleridir (Akmut, 1980: 13).

Türk hayat sigorta sektörünün gelişimi 2010-2016 dönemi için incelenmiş son 7 y1l içindeki verileri Tablo 1'de gösterilmiştir.

Tablo 1. Türk Hayat Sigorta Sektörünün 2010-2016 Yllları Sektör Verileri

\begin{tabular}{llllllll}
\hline Yıllar & $\mathbf{2 0 1 0}$ & $\mathbf{2 0 1 1}$ & $\mathbf{2 0 1 2}$ & $\mathbf{2 0 1 3}$ & $\mathbf{2 0 1 4}$ & $\mathbf{2 0 1 5}$ & $\mathbf{2 0 1 6}$ \\
\hline Şirket Sayısı & 26 & 27 & 27 & 27 & 28 & 28 & 28 \\
\hline Prim (Milyon TL) & 2.181 & 2.685 & 2.710 & 3.395 & 3.279 & 3.760 & 5.038 \\
\hline Değişim (\%) & 20,70 & 23,13 & 0,94 & 25,25 & $-3,40$ & 14,66 & 33,98 \\
\hline Toplam İçindeki Payı (\%) & 15,44 & 15,65 & 13,67 & 14,01 & 12,62 & 12,20 & 12,44 \\
\hline
\end{tabular}

Kaynak: Türkiye Sigorta Birliği 2016 Yı1ı Sektör Raporu.

Türkiye'de hayat branşında 2010 yılında 26 şirket faaliyet gösterirken, incelenen dönem içerisinde bu sayı artarak 2016'da 28 şirkete kadar çıkmıştır. Hayat Sigortaları hayat branşında 2014 yılını 3,3 milyar TL olan prim üretimi ile 2015 yılını ise \%19'luk artışla 3,8 milyar TL'ye yükseltmiştir. Hayat branşında 2015 yılında 3.760.993.289 TL olan prim üretimi 2016 yılında \%34'lük artışla 5.038.807.842 TL'ye çıkmıştır. Hayat branş1 prim gelirlerinin sektörün toplam prim gelirleri içindeki payı ise $\% 12,44$ olarak gerçekleşmiştir. 2016 yılına göre sigortalı sayısı \%0,7 oranında azalarak, 20,2 milyona düşmüştür (Türkiye Sigorta Birliği 2016 Yılı Sektör Raporu, 2017).

\section{i) Sigortalama Şekline Göre Hayat Sigortaları}

Sigortalanma şekline göre hayat sigortaları, ferdi hayat sigortaları ve grup hayat sigortaları olmak üzere iki grupta incelenir. 
-Grup hayat sigortaları, insanların karşı karşıya oldukları riskler için bir grup olarak tek sözleşme altında, bağlı oldukları kurum adına sigortalanması biçiminde düzenlenir. Düzenlenen sözleşmede sigortalılar ile sigortadan yararlanacak olan kişilerin isimleri belirtilmekte ve kurumda çalışan herkes sigorta güvencesinden yararlanmaktadır. Grup hayat sigortaları, bir iş yerinde çalışanlar, sendika üyeleri veya meslek kuruluşlarının mensupları tarafından daha çok tercih edilmektedir. Tercih sebebi, grup hayat sigortalarında ferdi hayat sigortalarına göre maliyetin daha düşük olmasıdır (Keçeci, 2002: 49).

-Ferdi hayat sigortası ise; kişilerin karşı karşıya kaldıkları riskler için, bireysel olarak hayat sigorta şirketleri ile yapmış oldukları sözleşmeleri kapsar (Akay, 2001: 32).

\section{ii) Taşıdıkları Risklere Göre Hayat Sigortaları}

Taşıdıkları riske göre hayat sigortaları, yaşama ihtimaline dayalı hayat sigortaları, ölüm ihtimaline dayalı hayat sigortaları ve karma hayat sigortaları olmak üzere üç grupta ayrılır.

-Yaşama ihtimaline karşı hayat sigortaları; sigorta sözleşmesinde belirtilen sürenin bitiminde sigortalının hayatta kalması halinde, poliçede belirtilen miktarda sermaye veya iradın ödenmesini sağlayan sigorta çeşididir (Çaldağ, 1982: 33). Bu tür hayat sigortaları, sigortalının sigorta şirketiyle yaptığ 1 sözleşme süresince hayatta kalması koşuluyla tazminat alabilmesi için düzenlendiğinden, sigortalı bu süre içinde yaşamını yitirdiği takdirde, mirasçıları sigorta şirketinden herhangi bir meblağ talep edemez (Keçeci, 2002: 53).

-Ölüm ihtimaline dayalı hayat sigortasında; sigortalının yaşına bağlı olarak belirlenen prim karşılığında, sigortalının ölümü halinde tazminat ödemesi mirasçılarına yapılmaktadır (Osmançavuşoğlu, 1999: 64).

-Karma Hayat Sigortalarl; Türkiye'de en yaygın hayat sigortası türü olan karma hayat sigortalarında, ölüm ihtimali ve hayatta kalma ihtimali bir arada yapılır. Belli bir süre içinde sigortalının ölmesi durumunda mirasçılarına vefat tazminatı ödenmesini sağlamasının yanında, sigortalı söz konusu süre sonunda hayatta kaldığı durumunda poliçede yazılı bedelin sigortalıya verilmesini öngören bir sigorta çeşididir. Dolayısıyla sınırlı süreli sigortadan farklı olarak, yalnızca sigortalının ölümü nedeniyle doğabilecek sonuçlara karşı yakınlarına fon sağlanmamakta, kişi sağ kaldığı takdirde geri kalan hayatı içinde bir fon oluşturmaktadır (Akay, 2001: 36).

\section{C- Hayat Dışı Sigortalar ve Türleri}

Hayat dışı sigortalar, işletme ve şahısların maddi varlıklarını tehdit eden para ile ölçülebilen risklere karşı bu varlıkların sigorta güvencesi altına alınmasını sağlamaktadır. Belirli bir prim karşılığında bu varlıklar sigorta kapsamına alınmaktadır. Hasarın gerçekleşmesi halinde sigorta bedeli sigortaciya ödenir (Sağlam, 1996: 20).

Hayat sigortası ve hayat dışı sigortalar arasında bazı farklılıklar bulunmaktadır. Bu farklilıklar;

a) Hayat sigortalarında kâr paylı sigorta primlerin önemli bir kısmı tasarruf amacına yönelik olduğundan, saklama payı oranları diğer sigorta branşlarına göre oldukça yüksektir. Bundan dolayı, hayat branşında üretilen primlerin çoğu yurt içinde kalır. Böylelikle hayat sigortasında biriken fonlar ekonomik gelişmeye katkıda bulunur (Elveren, 1994: 35).

b) Hayat sigortacılığında ve az sayıdaki hayat dışı branşta, kişisel kaza gibi, hasarların boyutu önceden belirlenir. Hayat dışı sigorta sektöründe ise hasarların boyutu değişebilir.

c) Hayat sigortacılığında hasarların riski, poliçelerin vadeleriyle bağlantılıdır. Bu nedenle sigorta şirketleri, giderek artan hasar ödemelerini gelecekteki yıllarda karşılayabilmek 
amacıyla prim gelirlerini yatırımlara aktarmak durumundadır. Hayat dışı sigorta sektöründe ise durum daha farklıdır.

d) Hayat sigortalarında (yıllık grup hayat sigortaları hariç) poliçelerin zamanı uzun dönemlidir. Hayat dışı sigortalarında ise bu süre 1 yıl ya da daha azdır ve dönem sonunda sigortalı ve sigortacı tarafından tekrarlanabilir özelliğe sahiptir.

e) Hayat dışı sigortalarda dönem sonu geldiğinde her yenileme için bir takım farklılıklar söz konusudur. Bunun sebepleri kişisel durumlarda meydana gelen değişiklikler ve bazı iş kollarında meydana gelen prim oranı değişikliklerinden kaynaklıdır (Elveren, 1994: 35).

Hayat dışı sigortaları; yangın, kaza, nakliyat, mühendislik, tarım (ziraat), özel sağlık sigortası ve diğer sigorta grupları altında incelenecektir.

\section{i) Yangın ve Doğal Afetler Sigortası}

Yangın sigortası özel veya ticari amaçla kullanılan her türden bina ve muhteviyatı, kendiliğinden meydana gelen yangın, yıldırım, infilak ile bunlardan kaynaklanan buhar, hararet, duman gibi tehlikelerin neden olduğu fiziki hasarlara karşı teminat altına alan sigorta türüdür.

Türkiye'de yangın sigortasının 2010-2016 dönemindeki gelişimi Tablo 2'de gösterilmektedir. Bu alanda faaliyet gösteren şirket sayıs1 2010 yılında 31 iken, 2016'ya kadar 3 şirketi daha bünyesine katarak, toplam 34 şirket bu alanda faaliyetlerini sürdürmektedir.

Tablo 2. 2010-2016 Dönemi Yangın ve Doğal Afetler Sektör Verileri

\begin{tabular}{llllllll}
\hline Yıllar & $\mathbf{2 0 1 0}$ & $\mathbf{2 0 1 1}$ & $\mathbf{2 0 1 2}$ & $\mathbf{2 0 1 3}$ & $\mathbf{2 0 1 4}$ & $\mathbf{2 0 1 5}$ & $\mathbf{2 0 1 6}$ \\
\hline Şirket Sayıs1 & 31 & 32 & 33 & 33 & 34 & 34 & 34 \\
\hline Prim (Milyon TL) & 1.980 & 2.309 & 2.645 & 3.324 & 3.845 & 4.383 & 4.827 \\
\hline Değişim (\%) & 3,61 & 16,64 & 14,56 & 25,67 & 15,66 & 13,97 & 10,15 \\
\hline Toplam İçindeki Payı1\%) & 14,01 & 13,40 & 13,34 & 13,72 & 14,80 & 14,22 & 11,92 \\
\hline
\end{tabular}

Kaynak: Türkiye Sigorta Birliği 2016 Y1lı Sektör Raporu.

Sigorta şirketlerinin yangın ve doğal afetler sigortası branşında son 7 yıllık dönem içerisindeki faaliyetleri sonucunda yurt içi ve yurt dışında olmak üzere toplam prim üretimi 2015 yılında 4.383.030.752 TL'ye ulaşmıştır. Prim üretiminin toplam prim gelirleri içindeki payı, incelenen dönem içerisinde 2014 yılında \% 14,80 ile en yüksek orana sahip olmuş, 2015 yllında ise bu oran \%14,22 değerine gerilemiştir.

Yangın ve doğal afet sigortaları branşı 2016 yılı sonunda bir önceki yıla göre $\% 10,1$ oranında büyümüş; zorunlu deprem sigortası hariç bırakıldığında ise branşın büyüme oranı $\% 9,5$ olarak gerçekleşmiştir. Zorunlu deprem sigortası \%12,77'lik bir büyüme gerçekleştirerek yangın branşını olumlu yönde etkilemiştir. Branşın hayat dışı prim üretimi içindeki payı, 2015 yılında 4,4 milyar TL prim üretimi ile \%16,19 iken, 2016 yılı sonunda 4,8 milyar TL prim üretimi ile \%13,62 olmuştur. 2015 yılında sigorta şirketlerinin teknik sonuçlarını olumsuz yönde etkileyen, özellikle ilk çeyrekte meydana gelen kar yağışı başta olmak üzere firtına ve sel gibi doğal afetler, 2016 yılında yaşanmamış; ancak söz konusu doğal afetler 2016 yılında yerini terör olaylarına bırakmıştır. 2016 yılında meydana gelen terör hasarlarının muallak hasar karşılıklarını artırmasıyla teknik kâr, 2015 yılına göre \%51 oranında azalış göstererek, 136 milyon TL olarak gerçekleşmiştir. Branşta 2015 yılında \%39,84 olan hasar prim oranı 2016'da \%39,14 olarak gerçekleşmiştir (Türkiye Sigorta Birliği 2016 Y1lı Sektör Raporu, 2017). 


\section{ii) Kaza Sigortası}

Kaza riski, işletmeler ve insanları korkutan en önemli riskler arasında yer almaktadır. Kaza, sigortalının beklemediği ve tasarlanmayan hasarlı olaydır. Başka bir ifadeyle kaza, dışarıdan ve aniden meydana gelen bilinçsiz bir olayın, sigortalının mal ve can varlığı üzerinde hasara yol açmasıdır (Sağlam, 1996: 22).

Kaza sigortası, kaza sonucu oluşan hasarları telafi edebilmek için yapılan sigorta türüdür. Kaza sigortasının amacı, sigortalının bir kaza sonucunda uğrayacağı ekonomik ve işgücü kayıplarının sigortacı tarafından ödenmesidir. 19. yüzyıldaki büyük sanayi devrimi, bunun endüstriye getirdiği makineleşme ve başlangıç aşamasında hata yapma olasılığı yüksek olan makine, araç ve gereçler özellikle kullanıcılarına yönelik tehlike ve riskleri de beraberinde getirmiştir. Bu olay kaza sigortalarına başlangıç teşkil etmiş ve zaman içinde kaza sigortaları bugünkü çeşitliliği yakalamıştır (Yaman, 2001: 28-29).

Kaza sigortası genellikle; oto, özel sağlık, mecburi mali mesuliyet, isteğe bağlı mesuliyet, işveren mali mesuliyet, hırsızlık, cam kırılması, uçak tekne kazası ve benzer konuları kapsamaktadır.

Tablo 3, 2010-2016 döneminde Türkiye'de kaza branşında faaliyet gösteren sigorta sektörünün verilerini göstermektedir. Bu alanda faaliyet gösteren şirket sayısı; 2010 yılında 55 iken, 2016'ya kadar 2 şirketi daha bünyesine katarak toplam 57 şirkete ulaşmıştır.

Tablo 3. 2010-2016 Dönemi Kaza Sigortalarının Sektör Verileri

\begin{tabular}{llllllll}
\hline Ylllar & $\mathbf{2 0 1 0}$ & $\mathbf{2 0 1 1}$ & $\mathbf{2 0 1 2}$ & $\mathbf{2 0 1 3}$ & $\mathbf{2 0 1 4}$ & $\mathbf{2 0 1 5}$ & $\mathbf{2 0 1 6}$ \\
\hline Şirket Sayıs1 & 55 & 57 & 57 & 58 & 58 & 57 & 57 \\
\hline Prim (Milyon TL) & 598 & 662 & 679 & 883 & 1.036 & 1.154 & 1.432 \\
\hline Değişim (\%) & 11,89 & 10,74 & 2,59 & 29,99 & 17,24 & 11,5 & 24,02 \\
\hline Toplam İçindeki Pay1(\%) & 4,24 & 3,86 & 3,43 & 3,65 & 3,99 & 3,75 & 3,54 \\
\hline
\end{tabular}

Kaynak: Türkiye Sigorta Birliği 2016 Yılı Sektör Raporu.

Kaza branşında prim üretimi 2016 yılında 2015 yılına göre \%24,02 oranında artarak 1.432.458.852 TL'ye ulaşmıştır. Kaza branş1 prim gelirlerinin toplam prim üretimi içindeki payı 2015 yılında \%3,75 iken bu oran, 2016 yılında \%3,54 olarak gerçekleşmiştir. 2015 yılında \%19,35 olarak gerçekleşen hasar prim oranı 2016 yılında \%21,39 olarak gerçekleşmiştir.

\section{iii) Nakliyat Sigortası}

Nakliyat sigortası, belli bir prim karşılığında insanların mallarını belirli bir yerden hareket edip, belli bir yere varıncaya kadar kara, deniz ve demiryolu ile yapılan yük ve yolcu taşıması sırasında ortaya çıkacak zararların sigorta yaptırmasıdır (Aktuğlu, 1984: 50). Bu nedenle nakliyat sigortasında, diğer sigorta dallarından farklı olarak, sadece belirli riskleri belirleyen "özellik ilkesi" yerine çeşitli riskleri kapsayan "genellik ilkesi” de önemlidir (Güvel ve Güvel, 2002: 110). Diğer sigorta dallarında belirli bazı riskler olmasına karşılık, nakliyat sigortasında taşıt aracına ya da mallara zarar verebilecek çok çeşitli riskler bulunmaktadır.

2010-2016 dönemi içerisinde ülkemizde sigorta sektörünün nakliyat branşındaki gelişmeleri Tablo 4'de gösterilmiştir. 2010 yılında şirket sayısı 31 iken, dönem içerisinde artarak bu sayı 2015 yılında 33'e çıkmıştır. 2016 yılında ise 1 şirket sektörden çıkmış ve nakliyat sigortası 32 şirket ile yoluna devam etmektedir. 
Özel Sağlık Sigortası Talebini Etkileyen Faktörlerin İkili Lojistik Regresyon Yöntemiyle Analizi: İstanbul Örneği

Tablo 4. 2010-2016 Dönemi Nakliyat Sigortalarının Sektör Verileri

\begin{tabular}{llllllll}
\hline Yıllar & $\mathbf{2 0 1 0}$ & $\mathbf{2 0 1 1}$ & $\mathbf{2 0 1 2}$ & $\mathbf{2 0 1 3}$ & $\mathbf{2 0 1 4}$ & $\mathbf{2 0 1 5}$ & $\mathbf{2 0 1 6}$ \\
\hline Şirket Sayısı & 31 & 31 & 32 & 31 & 33 & 33 & 32 \\
\hline Prim (Milyon TL) & 298 & 358 & 377 & 415 & 488 & 533 & 549 \\
\hline Değişim (\%) & 15.54 & 20.06 & 5.40 & 10.07 & 17.53 & 9.23 & 2.90 \\
\hline Toplam İçindeki Payı (\%) & 2.11 & 2.09 & 1.91 & 1.72 & 1.88 & 1.73 & 136 \\
\hline
\end{tabular}

Kaynak: Türkiye Sigorta Birliği 2016 Y1lı Sektör Raporu.

2016 yılında prim üretimi 549.455.623 TL olarak gerçekleşmiş ve bir önceki yıla göre cari fiyatlarla \%2,9 oranında artış göstermiştir. 2016 yılında nakliyat yük sigortaları prim üretimi artışı, özellikle dış ticaret hacminde yaşanan daralmanın etkisi ile sınırlı kalmış ve reel olarak negatif bir düzeyde gerçekleşmiştir. Ekonomik ve siyasi gelişmelere duyarlı olan nakliyat branşında bu yıl da geçen yıl olduğu gibi küresel büyümenin yavaşlaması ve mal ticaretindeki hareketliliğin zayıf kalması, Avrupa Birliğinde ekonomik faaliyetlerin önemli ölçüde hızını kaybetmesi, Irak ve Suriye'deki çatışmalar ile Rusya ile yaşanan gerilimin ticari aktiviteleri kısıtlaması, 15 Temmuz darbe girişimi sonrası yatırımların yavaşlaması, emtia bedellerinin düşüş yönlü seyretmesi, sigorta fiyat ve şartlarındaki rekabetin devam etmesi gibi hususların olumsuz etkileri hissedilmiştir. 2015 y1lında \%47,23 olarak gerçekleşen hasar prim oranı 2016 yılında \%40,55 olarak gerçekleşmiştir (Türkiye Sigorta Birliği 2016 Yılı Sektör Raporu, 2017).

\section{iv) Genel Zararlar Sigortası (Mühendislik Sigortası ve Tarım Sigortası)}

Genel zararlar sigortası kapsamında cam kırılması sigortası, hırsılık sigortası, "sigortas1, dolu sera sigortası, devlet destekli bitkisel ürün sigortası, devlet destekli sera sigortası, devlet destekli su ürünleri sigortası, hayvan hayat sigortası ve kümes hayvanları hayat sigortas1 türlerini kapsamaktadır. Kullanım alanı daha geniş olan mühendislik sigortası ve tarım sigortası açıklanacaktır (Türkiye Sigorta Birliği, [https://www.tsb.org.tr/sigortabranslari.aspx?pageID=622]. Erişim: 15.04.2019).

Mühendislik sigortası, makine sigortası, montaj sigortası olmak üzere iki alt grup altında incelenmektedir.

Makine sigortasl, tahmin edilemeyen ve ani olarak meydana gelecek her tür makine, makineli tesis, alet ve aygıt hasarlarının sebep olacağı mali kayıpları sigorta güvencesi altına alan bir sigorta türüdür (Güvel ve Güvel, 2002: 119-121).

Montaj sigortası, imalatı tamamlanmış, deneme dönemi geçmiş olan makinelerin tesisatın buharlı ve gazlı motorlu pompalarının hava kompresörlerinin çalışması sırasında hasara uğraması ya da bulundukları yerde dururken, temizlenirken, revizyonları yapılırken ve yerleri değiştirilirken beklenmedik bir etkiyle zarar görmelerinin bu sigortayla güvence altına alınmasidır.

Tarım sigortası uygulamada, dolu, meyve ve sebzeleri don vurması, sel baskını, hayvan hayat, hayvan hırsızlık ve yangın gibi geniş bir alana yayılmaktadır. Bunların arasında en çok uygulanan dolu sigortası ve hayvan hayat sigortasıdır.

2010-2016 dönemi içerisinde Türkiye'de sigorta sektörünün genel zararlar branşındaki gelişmeleri Tablo 5'de gösterilmiştir. 2010 yılında şirket sayısı 31 iken, dönem içerisinde artarak bu sayı 2016 yılında 34'e çıkmıştır. 
Sosyal Güvenlik Dergisi • Journal of Social Security • 2020/1

Tablo 5. 2010-2016 Dönemi Genel Zararlar Sigortası (Mühendislik ve Tarım Sigortası)

\begin{tabular}{llllllll}
\hline Yıllar & $\mathbf{2 0 1 0}$ & $\mathbf{2 0 1 1}$ & $\mathbf{2 0 1 2}$ & $\mathbf{2 0 1 3}$ & $\mathbf{2 0 1 4}$ & $\mathbf{2 0 1 5}$ & $\mathbf{2 0 1 6}$ \\
\hline Şirket Sayıs1 & 31 & 31 & 33 & 34 & 35 & 34 & 34 \\
\hline Prim (Milyon TL) & 993 & 1.473 & 1.743 & 2.186 & 2.429 & 2.977 & 3.498 \\
\hline Değişim (\%) & 9.84 & 48.38 & 18.32 & 25.4 & 11.09 & 22.56 & 17.52 \\
\hline Toplam İçindeki Payı (\%) & 7.03 & 8.59 & 8.79 & 9.03 & 9.35 & 9.66 & 8.64 \\
\hline
\end{tabular}

Kaynak: Türkiye Sigorta Birliği 2016 Yılı Sektör Raporu.

2016 yılında geçen yıla göre, hayat dışı branşlarda \%31 oranında büyüme gerçekleşirken mühendislik sigortaları aynı dönemde bir önceki döneme göre \%3,6 oranında bir artış kaydetmiştir. Mühendislik sigortaları alt branşları 2016 yılı prim üretimi artış oranlarına bakıldığında makine kırılması ve elektronik cihaz sigortalarında artış gözlenirken montaj ve inşaat sigortalarında bir düşüş görülmektedir. Hasar prim oranlarına baktığımızda mühendislik sigortalarında 2015 yılında \%77,3 iken 2016 yılı verilerine göre $\% 54,4$ oranında gerçekleşmiş gözükmektedir. Bu yükselişteki en önemli faktör \%103 olan 2015 yılı inşaat branşı hasar prim oranının, 2016 yılında \%27,7 olarak gerçekleşmesidir. Hasar prim oranındaki bu düşüşün, gerçekleşen hasar tutarının 2015 yılında 342,1 milyon TL iken 2016 yılında 98 milyon TL olmasından kaynaklandığı düşünülmektedir. Buna karşın bu dönemde kazanılmış prim 332,1 milyon TL'den 356,4 milyon TL'ye çıkarak sınırlı bir artış göstermiştir.

\section{v) Diğer Sigortalar}

Özel sigorta kapsamında hayat ve hayat dışı sigorta türleri açıklanmıştır. Hayat dışı sigorta grubu altında bu çalışmada yer almayan sigortalar diğer sigortalar grubu olarak sınıflandırılabilir. Bu sigorta grubu altında, inşaat sigortası, meslek sigortası, işletme faaliyetlerinin kesilmesine karşı sigorta, aşınma sigortası, hukuki koruma sigortası, ihracat ve ithalat sigortası, kredi sigortası vb. sigortalar yer almaktadır (Sağlam, 1996: 24).

\section{II- TÜRKIYE'DE ÖZEL SAĞLIK SIGORTASI VE EKONOMIDEKİ YERI}

Türkiye'de hızlı bir gelişme potansiyeline sahip olan özel sağlık sigortası kişilerin karşılaşacakları hastalıklara karşı kendilerini koruma isteğinden doğmuştur. Sigorta sektörleri arasında özel sağlık sigortası branşı hakkında bilgi bu bölümde verilecek daha sonra ise ekonomiye olan katkıları sunulacaktır.

\section{A- Özel Sağlık Sigortası Kavramı}

Özel sağlık sigortası bireylerin tedavi, tıbbi yardım ve ilaç harcamalarına karşı teminat veren sigorta branşıdır. Sigorta şirketlerinin tıbbi danışmanlarının onayı olmak kaydıyla, sigortalının, ameliyat, uzun veya kısa süreli tedaviler, ameliyat veya tedaviye bağlı ilaç giderleri gibi tüm harcamalarını, azami limitlerle tam veya muafiyet olarak karşılanmaktadır. Sigorta şirketlerinin uygulamalarında farklılıklar olmakla birlikte, periyodik olarak yapılan sağlık kontrolleri, herhangi bir tıbbi nedeni olmaksızın ve buna benzer harcamalar, genel olarak teminat harici tutulmaktadır (Türkiye Sigorta Birliği, [https://www.tsb.org.tr/yayinlar.aspx?pageID=534]. Erişim: 25.06.2019).

Özel Sağlık Sigortalarının başlıca iki ana teminatı vardır. Bunlardan ilki "Yatarak Tedavi Teminatı" ikincisi ise "Ayakta Tedavi Teminatıdır". 
Yatarak Tedavi Teminatı, ameliyatlı ya da ameliyatsız hastanede yatarak yapılan tedaviler için hastaneye yatış çıkış dönemi içindeki, doktor, ameliyathane, asistan, anestezi, gerekli ve zorunlu diğer tıbbi hizmetlere ait sigortalının hastanede tedavi gördüğü süre içerisinde oluşacak giderler ile yoğun bakım ve ambulans giderlerini içerir.

Ayakta Tedavi Teminatı ise doktor muayene, teşhis yöntemleri (MR, tomografi ve laboratuvar tetkikleri gibi), küçük müdahalelerin girdiği ayakta tedaviler ve ilaç giderlerinden oluşur. Ayrıca bu iki ana teminat başlığına ek olarak, fazladan prim ödemek koşulu ile gözlük (cam/çerçeve/lens) ve dişin kapsandığ 1 üçüncü bir teminat grubu vardır.

Özel sağlık sigortasının en önemli olumsuz yönü prim miktarını oluşturulmasında yaşanan sorunlar ve yardım paketlerinin hesaplanmasında yaşanan sorunlardır. Sağlığı yerinde olmayan kişilerin, özel sağlık sigortasını tercih edememelerinin önündeki en büyük engel fiyatlarının yüksek olmasıdır.

Özel sağlık sigortasının kapsamı ve ödeyeceği prim miktarı sigorta yaptıracak olan kişinin demografik özellikleri önemli rol oynamaktadır. Hastalanma sıklığı yaralanma oranlarına göre prim miktarı belirlenmektedir. Özel sağlık sigortaları kâr amaçlı işletmeler olduğu için genellikle yüksek risk grubu olarak adlandırılan ve bu grupta yer alan; yaşlı, sakat, kronik hastalığ́ olan vb. kişileri sigorta yaptırmaktan kaçınmaktadırlar (Tıraş, 2013: 125-152).

\section{B- Türkiye’de Özel Sağlık Sigortasının Gelişimi}

Türkiye' de özel sağlık sigortacılığı faaliyetleri 1870'li yıllardan sonra en çok yabancıların sigorta şirketleri olarak işlem yapmaktaydılar. 1923 yılında Cumhuriyetin ilanından sonra "Sigortacılık Kulübü" kurulmuştur.

Bu kulüp 1927 tarihinde yerini "Sigortacılar Cemiyeti Daire-i Merkeziyesi" ne bırakmıștır. Daha sonra bu kuruluş 1975 yılında " Türkiye Sigorta ve Reasürans Şirketleri Birliği" adı altında faaliyet göstermiştir (Yıldırım ve Akbulut, 2012: 135-139).

1862 yılından önce Türkiye'de sigorta sayılabilecek bir uygulamaya rastlamak çok zordu. Osmanlı ve Selçuklu Devletlerinde görülen vakıf ve loncalar daha çok yardım kuruluşları olarak çalışıyorlardı. 1982 yılında Riunioni Adriaticadi Sigurta adlı İtalyan şirketi ülkemizde faaliyete başlamıştır (Avşar, 2010: 62).

Türkiye’de özel sağlık sigortacılığı 1983 yılında işverenlerin çalışanlarının primlerini ödemesi şeklinde grupları kapsayan bir uygulama şeklinde başlamış daha sonra 1988 yılı itibariyle fertlere de uygulanmaya başlanmıştır (Arık, 2010: 116-118).

Türkiye' de ilk özel sağlık sigortası uygulamasını Ziraat Bankası tarafından başlatılmıştır.

1990 yılından önce sağlık sigortası uygulaması sadece kaza sigortalarında, sigortalılara kaza sonucu tıbbi harcamaların karşılığında, tazminat ödenmesinden oluşmaktaydı. 1990 yılından sonra çok hızlı bir gelişme gösteren özel sağlık sigortacılığı Türkiye'nin en hızlı büyüyen sigorta faaliyeti olmuştur (Tiryaki ve Tatar, 2000: 129-130).

1991 yılı itibariyle Türkiye'de uygulanmaya başlayan özel sağlık sigortaları Türk Ticaret Kanunu'nda (TTK) belirtilen çeşitli sigorta türleri içerisindeki kaza sigortalarının kapsamı dâhilinde uzun bir süre yerini alan ve hâlâ genel şartları Hazine Müsteşarlığ́1 tarafından onaylanmış sekiz sigortanın içerisinde yerini korumaktadır (Filiz, 2010: 57-58).

Literatürde özel sigorta tercihini etkileyen faktörlerin incelenmesi ile ilgili çok fazla çalışmaya rastlanılamamıştır. Yapılan çalışmalar genellikle ülkelerin ve özel sigorta şirketlerin verilerine dayanan yorumlamalara dayanmaktadır. Bu çalışmalardan bazıları 
ülkelerin geneli için refah ve gelirin özel sigorta sahibi olmayı nasıl etkilediğini anlamaya çalışmaktadır.

\section{C- Türkiye'de Özel Sağlık Sigortasının Ekonomiye Katkısı ve Prim Üretim Düzeyi}

Özel sağlık sigortası yıllar itibariyle bakıldığında prim üretim düzeyinde sürekli bir artış görülmektedir. 2010 yılında 33 şirket ile faaliyet gösteren sektörde, 2012 yılında bu rakam 37'ye kadar çıkmıştır. 2016 yılına gelindiğinde ise birlikten 1 şirket ayrılmıştır. 36 şirket faaliyet göstermektedir.

2011 yılında 34 şirketin faaliyet gösterdiği özel sağlık sigortası branşında prim gelirleri 1.998 milyon TL gelire yükselmiş ve bir önceki yıla göre cari fiyatlardan \%17,20 oranında bir artış gerçekleşmiştir (Türkiye Sigorta Birliği 2011 Yılı Faaliyet Raporu, 2012).

Tablo 6. Türkiye'de Özel Sağlık Sigortasının 2010-2016 Prim Üretim Düzeyi

\begin{tabular}{llllllll}
\hline Yıllar & $\mathbf{2 0 1 0}$ & $\mathbf{2 0 1 1}$ & $\mathbf{2 0 1 2}$ & $\mathbf{2 0 1 3}$ & $\mathbf{2 0 1 4}$ & $\mathbf{2 0 1 5}$ & $\mathbf{2 0 1 6}$ \\
\hline Şirket Sayıs1 & 33 & 34 & 37 & 34 & 34 & 36 & 36 \\
\hline Prim (Milyon TL) & 1.705 & 1.998 & 2.227 & 2.472 & 2.929 & 3.435 & 4.226 \\
\hline B.Ö.Y.G.D. (\%) & 20,51 & 17,20 & 11,43 & 11,01 & 18,49 & 17,28 & 23,00 \\
\hline Toplam İçindeki Payı(\%) & 12,07 & 11,64 & 11,23 & 10,20 & 12,9 & 12,6 & 10,44 \\
\hline
\end{tabular}

Kaynak: Türkiye Sigorta Birliği 2016 Yılı Sektör Raporu.

2013 yılına gelindiğinde 34 şirket ile yoluna devam eden birlik prim gelirini de 2.472 milyon TL olarak gerçekleştirmiştir. Bir önceki yıla göre cari fiyatlar üzerinden \%11,01 oranında artmıştır (Türkiye Sigorta Birliği 2013 Yılı Faaliyet Raporu, 2014).

2015 yılında sektörün kârlılığını artıran önemli iki gelişme yaşanmıştır. Bunlar yabancılar için sağlık sigortasının varlığı ve mali gelirde yaşanan artış olmuştur. Özel sağlık sigortası gelir ve kârlılıkta büyük ölçüde büyüme potansiyeline sahiptir. Tamamlayıcı sağlık sigortacılığının ürünler arasında yerini almış olması da sağlık branşında 2015 yılı içerisinde de yeni sigortalı kazanımının devam etmesini sağlamıştır. 2015 yılı itibariyle 3.435 milyon TL prim üretimi gerçekleşmiştir. Bir önceki yıla göre cari fiyatlarla $\% 17,28$ oranında artış görülmüştür (Türkiye Sigorta Birliği 2015 Y1lı Sektör Raporu, 2016).

2016 yılında 217.282 adetlik bir poliçe sayısına ulaşılması bunun bir göstergesi olmuştur. Genel olarak sağlık branşında kârlılık açısından olumlu gelişmeler devam etmiş, sağlık branşı, 2016 yıl sonu itibarı ile 81.336.994 TL teknik kâra ulaşmıştır. 35 şirketin faaliyet gösterdiği 2016 yılı sonunda hastalık-sağlık branşı kazanılmış primleri 3.861.482.093 TL'ye, gerçekleşen tazminatlar da, 3.003.018.291 TL'ye yükselmiştir (Türkiye Sigorta Birliği 2016 Y1lı Sektör Raporu, 2017).

\section{III- MATERYAL VE METOT}

Sosyal bilimler bünyesinde yapılan çalışmanın hedefine yönelik bir araştırma yöntemi tespit etmek, sonuçların anlam taşıması açısından önem taşır. Çünkü bazı araştırmalar içerisinde amaç; değişkenler arasında neden - sonuç ilişsisini ortaya koymak olabileceği gibi ilgilenilmekte olan kütlenin veya olayın belirli özelliklerinin gösterilmesi veya tanıtılması ile olur. Bu bağlamda araştırmalar deney, tanıtım, istatistik veya alan araştırmaları şeklinde tasniflenir. Bundan dolayı bu çalışma alan araştırması kapsamındadır. Veri toplama yöntemleri anket, deney, gözlem ve projeksiyon olmak üzere dört gruba ayrılır. Bu çalışma içerisinde veri toplama yöntemi olarak anket tekniği seçilmiş ve uygulanmıştır. Anket 
yöntemi bireylerle mülakat şeklinde olmuştur. Anket yönteminin tercih edilme nedeni olarak betimsel çalışmalarda fayda sağlaması ve daha az maliyetle daha hızlı veri toplamaya yardımcı olmasidır.

Çalışmada kullanılan veri seti; Mart 2017 Haziran 2017 döneminde İstanbul ili genelindeki 45 yaş üzeri kişilere yüz yüze mülakat şeklinde gerçekleştirilmiştir. Soru formunun oluşturulmasında Yong-Woo Lee'nin 2012 yılında yayımladığı çalışmasından yararlanılmıştır. Soru formunda ilk olarak katılımcıların demografik bilgilerini öğrenmeye yönelik sorulara yer verilmiştir. Katılımcıların demografik özelliklerini sormadaki amaç bireylerin demografik özelliklerindeki farklılıkların özel sağlık sigortası poliçesi almalarını etkileyip etkilemediğini öğrenmeye yöneliktir. Katılımcıların yaşlarını 45 yaş ve üzerinde olması ise yaş ilerledikçe poliçeli sayısında bir artış olacağı beklentisidir. Bireyin mal satın almasında sahip olduğu gelir düzeyinin önemli olduğu kesindir. Bu sebeple bireyin sahip olduğu gelir düzeyinin özel sağlık sigortası satın almayı hangi yönde etkileyeceği saptanmaya çalışılmıştır. Özel sağlık poliçesi satın almada bireyin sahip olduğu mal varlığı da önemlidir. Bu nedenle katılımcıların mal varlıklarının değeri de dikkate alınmıştır.

Soru formuna nihai şeklini vermeden önce varsa eksiklikleri görmek adına taslak halinde bir anket formu oluşturulmuş ve 20 kişiye uygulanmıştır. Pilot anket uygulamasından başarı elde ederek, birkaç soru takviyesiyle son halini almıştır. Eksik bilgi verileceği ve yanlış veriler elde edilebileceğinden ötürü örnek büyüklüğünün üzerinde bir rakam olan 400 adet anket uygulanmış bunlardan 17 adedi yanlış ve eksik veri içerdiğinden dolayı elemeye tabi tutulmuştur. Böylelikle geriye kalan 383 adet değerlendirme kapsamına alınmıştır.

İlk olarak anketlerden elde edilen veriler SPSS programına girilmiştir. Frekans analizinden sonra Lojistik Regresyon analizi uygulanmıştır. Böylece özel sağlık sigortası satın alma olasılığını etkileyen faktörler ve bu faktörlerin etkili olma dereceleri ortaya konulmaya çalışılmıştır. Logit modeli açıklayan Lojistik dağılım fonksiyonu aşağıdaki şekilde gösterilebilir (Yayar vd., 2015: 608):

$$
P_{i}=E\left(Y_{i}=\frac{1}{X_{i}}=\frac{1}{1+e^{-\left(\beta_{1}+\beta_{2} X_{i}\right)}}\right.
$$

Neden sonuç ilişkisine bağlı olarak yapılan çalışmalarda bazen bağımlı değişkende olumluolumsuz, evet-hayır, başarılı-başarısız gibi iki şıklı soruların olduğu veriler yer alır. Bu tip analizlerden en doğru sonucu almak adına Lojistik Regresyon Modeli uygulanmaktadır. Lojistik regresyon analizinin özünde bağımlı değişken ve bağımsı değişken veya değişkenler arasındaki ilişkiyi incelemek vardır (Yayar vd., 2015: 608).

Özel sağlık sigortası tercihinde iki alternatif söz konusu olur. Bu açıdan çalışmada ikili tercih modellerinden biri olan lojistik regresyon modeli tercih edilmiştir.

Lojistik regresyon analizinin aslına bakıldığında regresyon analizi olduğu görülmektedir. Ancak regresyon analizinden farklı üç önemli noktası vardır. Bunlar:

- Lojistik Regresyon Analizinde bağlı değişkenlerin alacağı değerlerden birisinin gerçekleşme olasılığı tahmin edilmektedir. Regresyon da ise bağımlı değişkenin değeri tahmin edilebilmektedir.

- Lojistik Regresyon analizinde bağımlı değişken kesikli bir değerdir. Hâlbuki regresyon analizinde bağımlı değişken süreklidir.

- Doğrusal regresyon analizinde bağımsızdeğişkenlerin çoklu normal dağılım göstermesi şartı aranırken, lojistik regresyonun uygulanabilmesi için bağımsız değişkenlerin dağılımına ilişkin hiçbir ön koşul bulunmamaktadır (Coşkun vd., 2004: 43). 


\section{IV- ARAȘTIRMA BULGULARI}

$\mathrm{Bu}$ araştırmada, İstanbul ilinde yaşayan 45 yaş üstü bireylerin özel sağlık sigortası satın almalarını belirlemede etkili olan sosyoekonomik, demografik özellikleri, hastalık durumları ve alışkanlıkları gibi değişkenler tespit edilmeye çalışılmıştır. $\mathrm{Bu}$ amaçla, öncelikle çalışmada ekonometrik analizde yer verilen değişkenler ile ilgili tanımlayıcı istatistikler sunulacak ve bulguların açıklanmasına geçilecektir.

\section{A- Katılımcıların Sosyoekonomik ve Demografik Özellikleri}

Araştırmada katılımcılara ait demografik, sosyoekonomik ve sağlık durumları ile ilgili özellikler Tablo 7'de verilmiştir. Buna göre; 383 kişinin 257'si (\%67,1) erkek, geri kalan 126 'sı (\%32,9) kadındır. Katılımcıların çoğunluğu (\%82,8) evli, \%35,8'i ilköğretim mezunu, $\% 36,6$ 's1 lise mezunu ve \%19,6 üniversite mezunudur. Emekli olanların oranı \%45,7, çoğunluğu $(69,2)$ orta gelir grubunda (3.000 TL-10.000 TL) yer alır. Katılımcıların çoğunluğunun $(\% 33,4)$ serveti 100 bin ile 500 bin TL arasındadır. Katılımcılardan 337'sinin $(\% 88,0)$ özel sağlı sigortası yokken $46(\% 12,0)$ kişinin özel sağlık sigortaları vardır. Katılımcıların \%97,4'si kent kökenlidir.

Tablo 7. Katılımcıların Sosyoekonomik ve Demografik Özellikleri

\begin{tabular}{|c|c|c|c|c|c|}
\hline Özellikler & Frekans & Yüzde & Özellikler & Frekans & Yüzde \\
\hline Cinsiyet & & & Özel Sağlık Sigortası & & \\
\hline Kadın & 126 & 32,9 & Hayır & 337 & 88,0 \\
\hline Erkek & 257 & 67,1 & Evet & 46 & 12,0 \\
\hline Medeni Durum & & & Yaşanılan Yer & & \\
\hline Evli & 317 & 82,8 & Kır kökenli & 10 & 2,6 \\
\hline Bekâr & 42 & 11,0 & Kent kökenli & 373 & 97,4 \\
\hline Boşanmış & 24 & 6,3 & & & \\
\hline$\overline{\text { Eğitim Durumu }}$ & & & Servet & & \\
\hline Okur-yazar Değil & 12 & 3,1 & $5.000-10.000$ & 76 & 19,8 \\
\hline İlköğretim & 137 & 35,8 & $10.000-50.000$ & 69 & 18,0 \\
\hline Lise & 140 & 36,6 & $50.000-100.000$ & 66 & 17,2 \\
\hline Üniversite & 75 & 19,6 & $100.000-500.000$ & 128 & 33,4 \\
\hline Lisansüstü & 19 & 5,0 & 500.000 ve üzeri & 44 & 11,5 \\
\hline$\overline{M e s l e k ~ D a g ̆ ı l ı m \imath ~}$ & & & Gelir & & \\
\hline İşsiz & 11 & 2,9 & Düşük & 50 & 13,1 \\
\hline Serbest meslek & 56 & 14,6 & Orta & 265 & 69,2 \\
\hline İşçi & 26 & 6,8 & Yüksek & 66 & 17,2 \\
\hline Emekli & 175 & 45,7 & Çok yüksek & 2 & 0,5 \\
\hline Ev hanımı & 61 & 15,9 & & & \\
\hline Memur & 42 & 11,0 & & & \\
\hline Yönetici & 12 & 3,1 & & & \\
\hline
\end{tabular}

Katılımcıların hastalık türlerine göre durumları Tablo 8'de verilmiş ve aşağıda kısaca özetlenmiştir: İleri düzeyde diyabet hastalığı olanlar \%4,4, yüksek tansiyon hastalığı olanlar $\% 5,0$, göz hastalığı olanlar \%5,5 oranındadır. Katılımcıların \%18,5'i diyabet, \%10,4'ü kalpdamar, \%23'ü yüksek tansiyon, \%8,1'i psikiyatri, \%25,3'ü göz hastasıdır. 
Özel Sağlık Sigortası Talebini Etkileyen Faktörlerin İkili Lojistik Regresyon Yöntemiyle Analizi: İstanbul Örneği

Tablo 8. Katılımcıların Hastalık Türüne Göre Durumları

\begin{tabular}{|c|c|c|c|c|c|c|c|c|}
\hline \multirow[t]{2}{*}{ Hastalık Türü } & \multicolumn{2}{|c|}{ Hayır } & \multicolumn{2}{|c|}{$\begin{array}{l}\text { Başlangıç } \\
\text { Düzeyinde }\end{array}$} & \multicolumn{2}{|c|}{$\begin{array}{l}\text { Normal } \\
\text { Düzeyde }\end{array}$} & \multicolumn{2}{|c|}{ İleri Düzeyde } \\
\hline & Sayı & $\%$ & Sayı & $\%$ & Sayı & $\%$ & Sayı & $\%$ \\
\hline Diyabet & 312 & 81,5 & 21 & 5,5 & 33 & 8,6 & 17 & 4,4 \\
\hline Kanser & 375 & 97,9 & 4 & 1,0 & 3 & 0,8 & 1 & 0,3 \\
\hline Kronik Akciğer & 373 & 97,4 & 3 & 0,8 & 3 & 0,8 & 4 & 1,0 \\
\hline Karaciğger & 370 & 96,6 & 7 & 1,8 & 4 & 1,0 & 2 & 0,5 \\
\hline Kalp-damar & 343 & 89,6 & 15 & 3,9 & 17 & 4,4 & 8 & 2,1 \\
\hline Beyin Damar & 371 & 96,9 & 6 & 1,6 & 3 & 0,8 & 3 & 0,8 \\
\hline Böbrek Yetmezliği & 372 & 97,1 & 4 & 1,0 & 5 & 1,3 & 2 & 0,5 \\
\hline By-Pass & 363 & 94,8 & 1 & 0,3 & 11 & 2,9 & 8 & 2,1 \\
\hline Sedef & 381 & 99,5 & 2 & 0,5 & & & & \\
\hline Alzheimer & 380 & 99,2 & 3 & 0,8 & & & & \\
\hline Menüsküs Yaralanmaları & 369 & 96,3 & 2 & 0,5 & 11 & 2,9 & 1 & 0,3 \\
\hline Zatürre & 376 & 98,2 & 5 & 1,3 & 1 & 0,3 & 1 & 0,3 \\
\hline Deri Kanseri & 372 & 97,1 & 8 & 2,1 & 3 & 0,8 & & \\
\hline Yüksek Tansiyon & 295 & 77,0 & 28 & 7,3 & 41 & 10,7 & 19 & 5,0 \\
\hline Astım & 359 & 93,7 & 12 & 3,1 & 5 & 1,3 & 7 & 1,8 \\
\hline Kulak Burun Boğaz & 345 & 90,1 & 17 & 4,4 & 10 & 2,6 & 11 & 2,9 \\
\hline Kalp Yetmezliği & 365 & 95,3 & 11 & 2,9 & 4 & 1,0 & 3 & 0,8 \\
\hline Psikiyatrik Sorun & 352 & 91,9 & 20 & 5,2 & 8 & 2,1 & 3 & 0,8 \\
\hline İleri Görüntüleme (MR) & 364 & 95,0 & 8 & 2,1 & 8 & 2,1 & 3 & 0,8 \\
\hline Göz & 286 & 74,7 & 37 & 9,7 & 39 & 10,2 & 21 & 5,5 \\
\hline
\end{tabular}

Katılımcıların sağlığını etkileyebilen faaliyetleri yapma sıklıklarına ilişkin veriler Tablo 9'da verilmiş olup aşağıda kısaca özetlenmiştir:

Tablo 9. Katılımcıların Să̆lı̆̆ını Etkileyebilen Faaliyetleri Yapma Sıklı̆̆ı

\begin{tabular}{|c|c|c|c|c|c|c|c|c|c|c|}
\hline \multirow{2}{*}{ Faaliyet Türü } & \multicolumn{2}{|l|}{ Hiç } & \multicolumn{2}{|c|}{ Çok Nadir } & \multicolumn{2}{|c|}{ Bazen } & \multicolumn{2}{|c|}{ Sık Sik } & \multicolumn{2}{|c|}{ Daima } \\
\hline & $\overline{\text { Sayı }}$ & $\%$ & Sayı & $\%$ & Sayı & $\%$ & Sayı & $\%$ & Sayı & $\%$ \\
\hline Sigara Kullanma & 210 & 54,8 & 27 & 7,0 & 9 & 2,3 & 29 & 7,6 & 108 & 28,2 \\
\hline Alkol Alma & 274 & 71,5 & 46 & 12,0 & 29 & 7,6 & 8 & 2,1 & 26 & 6,8 \\
\hline Egzersiz Yapma & 92 & 24,0 & 72 & 18,8 & 95 & 24,8 & 69 & 18,0 & 55 & 14,4 \\
\hline Depresyon Problemi Yaşama & 266 & 69,5 & 51 & 13,3 & 44 & 11,5 & 14 & 3,7 & 8 & 2,1 \\
\hline $\begin{array}{l}\text { Dumansız Temiz Havada } \\
\text { Bulunmaya Özen Gösterme }\end{array}$ & 64 & 16,7 & 26 & 6,8 & 50 & 13,1 & 85 & 22,2 & 158 & 41,3 \\
\hline $\begin{array}{l}\text { Düzenli Sağlık Kontrolü } \\
\text { Yaptırma }\end{array}$ & 92 & 24,0 & 34 & 8,9 & 67 & 17,5 & 69 & 18,0 & 121 & 31,6 \\
\hline Sağllklı Besinler Tüketme & 24 & 6,3 & 37 & 9,7 & 106 & 27,7 & 89 & 23,2 & 127 & 33,2 \\
\hline $\begin{array}{l}\text { Doktorun Yapmış Olduğu } \\
\text { Uyarıları Dikkate Alma }\end{array}$ & 33 & 8,6 & 26 & 6,8 & 50 & 13,1 & 70 & 18,3 & 204 & 53,3 \\
\hline $\begin{array}{l}\text { Tedavi İçin Verilen İlaçları } \\
\text { Vaktinde Alma }\end{array}$ & 31 & 8,1 & 17 & 4,4 & 26 & 6,8 & 63 & 16,4 & 246 & 64,2 \\
\hline $\begin{array}{l}\text { Herhangi Bir Rahatsılikla } \\
\text { Karşılaş1dıı̆ında Hemen } \\
\text { Önlem Alma }\end{array}$ & 25 & 6,5 & 17 & 4,4 & 42 & 11,0 & 81 & 21,1 & 218 & 56,9 \\
\hline
\end{tabular}


Daima sigara kullananlar \%28,2 alkol alanlar \%6,8 egzersiz yapanlar \%14,4 dumansız temiz havada bulunmaya özen gösterenler $\% 41,3$ düzenli sağlık kontrolleri yaptıranlar \%31,6 sağlıklı besinler tüketmeye çalışanlar \%33,2 oranındadır. Yine daima doktorun yapmış olduğu uyarıları dikkate alanlar \% 53,3 tedavi için verilen ilaçları vaktinde alanlar $\% 64,2$ ve herhangi bir rahatsızlıkla karşılaşıldığında hemen önlem alanların oranı \%56,9'dur.

Katılımcılardan hiç sigara kullanmayan \%54,8 alkol almayan \%71,5 depresyon problemi yaşayamayan \%69,5 ve dumansız temiz havada bulunmaya özen göstermeyenlerin oranı $\% 16,7$ olarak tespit edilmiştir. Katılımcıların sağlığını etkileyebilen diğer faaliyetleri yapmama oranları ise \%10'un altındadır.

Tablo 10'da bireylerin kendi sağlık durumlarını nasıl hissettikleri ile özel sigorta tercihi arasındaki bilgiler yer almaktadır.

Tablo 10. Katılımcıların Özel Sağlık Sigortası Sahipliği ile Sağlık Durumları İlişkisi

\begin{tabular}{|c|c|c|c|c|c|c|c|c|}
\hline & & & \multicolumn{2}{|c|}{$\begin{array}{lc}\text { Kendi } & \text { Sağlık } \\
\text { Düşünüuyorsunuz } \\
\end{array}$} & \multirow{2}{*}{$\begin{array}{r}\text { Durumunuzun } \\
\text { Normal }\end{array}$} & \multirow{2}{*}{$\begin{array}{c}\text { Nasıl } \\
\text { İyi }\end{array}$} & \multicolumn{2}{|l|}{ Olduğunu } \\
\hline & & & Çok kötü & Kötü & & & Çok iyi & Toplam \\
\hline \multirow{8}{*}{ 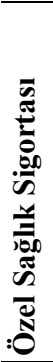 } & \multirow{4}{*}{ Hayır } & Sayı & 58 & 161 & 101 & 14 & 3 & 337 \\
\hline & & Ö.S.S. \% & 17,2 & 47,8 & 30,0 & 4,2 & 0,9 & 100,0 \\
\hline & & B.S.D. \% & 93,5 & 84,7 & 91,0 & 82,4 & 100,0 & 88,0 \\
\hline & & Toplam \% & 15,1 & 42,0 & 26,4 & 3,7 & 0,8 & 88,0 \\
\hline & \multirow{4}{*}{ Evet } & Sayı & 4 & 29 & 10 & 3 & 0 & 46 \\
\hline & & Ö.S.S. \% & 8,7 & 63,0 & 21,7 & 6,5 & 0,0 & 100,0 \\
\hline & & B.S.D. \% & 6,5 & 15,3 & 9,0 & 17,6 & 0,0 & 12,0 \\
\hline & & Toplam \% & 1,0 & 7,6 & 2,6 & , 8 & 0,0 & 12,0 \\
\hline \multirow{4}{*}{\multicolumn{2}{|c|}{ Toplam }} & Sayı & 62 & 190 & 111 & 17 & 3 & 383 \\
\hline & & Ö.S.S. \% & 16,2 & 49,6 & 29,0 & 4,4 & 0,8 & 100,0 \\
\hline & & B.S.D. \% & 100,0 & 100,0 & 100,0 & 100,0 & 100,0 & 100,0 \\
\hline & & Toplam \% & 16,2 & 49,6 & 29,0 & 4,4 & 0,8 & 100,0 \\
\hline
\end{tabular}

Ö.S.S.: Özel Sağlık Sigortası, B.S.D.: Bireyin Sağlık Durumu

Kendi sağlık durumunu çok kötü olarak değerlendirenlerin sayısı; 62 (\%16,2), kötü diyenlerin sayısı; $190(\% 49,6)$, normal diyenlerin sayısı; $111(\% 29,0)$, iyi olarak değerlendirenlerin sayısı; $17(\% 4,4)$ ve çok iyi diyenlerin sayısı; $3(\% 0,8)$ 'dir. Özel sağlık sigortası yaptırmayan kişilerden \%17,2'si sağlık durumunu çok kötü, \%47,8'i kötü, \%30,0'1 normal ve \%0,9'u çok iyi olarak belirtmişlerdir. Özel sağlık sigortası yaptıran kişilerden $\% 8,7$ 'sinin sağlık durumunu çok kötü, \%63,3'ünün kötü, \%21,7'sinin normal ve \%6,5'ininki iyidir. Katılımcılardan sağlık durumu çok kötü olanların \%93,5'i özel sağlık sigortası tercih etmezken bu oran sirasıyla kötü hissedenlerde \%84,7 normal hissedenlerde \%91,0 iyi hissedenlerde \%82,4 ve çok iyi hissedenlerde ise \%100'dür. Özel sağlık sigortası yaptırmanın bireyin sağlık durumuyla çok ilişkili olmadığı söylenebilir.

\section{B- İkili Lojistik Regresyon Analizi Sonuçları}

Bu bölümde araştırma konusu bireyin özel sağlık sigortası tercihini etkileyen faktörlerin neler olduğu binary logit modelle incelenmiştir. İncelenen bağımlı ve açıklayıcı değişkenlere iliş̧in tanımlamalar ve istatistikî sonuçlar Tablo 11 'de sunulmuştur. Araştırmadaki bağımlı değişken kategorik ve iki şıklı olup, İstanbul ilindeki 45 yaş üstü kişilerin özel sağlık sigortası poliçesi alıp almama durumlarıdır. Bu değişken nominal ölçekle ölçülmüştür. Çalışmada 
bağımlı değişkenle ilişkili olabileceği düşünülen çok sayıda bağımsız değişken de bulunmaktadır. Bağımsız değişkenlerin bazıları nominal ölçekle, bazıları ordinal ölçekle ölçülmüştür.

Araştırmada ana kütleyi İstanbul ilindeki 45 yaş üzerinde olan kişiler oluşturmaktadır. Bağımlı değişken özel sağlık sigortası yaptırma-yaptırmama durumudur. Özel sağlık sigortası yaptırma 1 ile yaptırmama 0 ile kodlanmıştır. Veriler 45 yaş üzerinde olan 383 kişiden derlenmiştir. Modelde bağımsız değişkenlere ilişsin kodlamalar ve tanımlayıcı istatistikler Tablo 11'de verilmiştir.

Tablo 11. Değişkenlere Ait Tanımlayıcı İstatistikler

\begin{tabular}{|c|c|c|c|}
\hline Değişken & Değişken tanımı $(n=383)$ & Ortalama & $\begin{array}{c}\text { Standart } \\
\text { sapma }\end{array}$ \\
\hline ÖSS & Özel sağlık sigortası sahipliği (Evet=1; Hayır=0) & 0,1201 & 0,32551 \\
\hline$Y A S ̧$ & Yaş durumu & 56,8616 & 9,54483 \\
\hline$G L R$ & $\begin{array}{l}\text { Aylık ortalama gelir }(\mathrm{TL})(\text { düşük=1; orta=2; yüksek=3; } \\
\text { çok yüksek=4) }\end{array}$ & 2,0522 & 0,56734 \\
\hline$E \breve{G} T M$ & $\begin{array}{l}\text { Eğitim düzeyi (okur-yazar değil=1; ilkokul=2; lise=3; } \\
\text { üniversite=4; yüksek lisans ve üzeri=5) }\end{array}$ & 2,8747 & 0,92943 \\
\hline$S R V T$ & $\begin{array}{l}\text { Servet durumu }(\mathrm{TL})(5.000-10.000=1 ; 10.000- \\
50.000=2 ; 50.000-100.000=3 ; 100.000-500.000=4 ; \\
500.000 \text { ve üzeri=5) }\end{array}$ & 2,9869 & 1,33120 \\
\hline$K R C \breve{G} R$ & $\begin{array}{l}\text { Karaciğer hastalığ }(\text { hayır }=1 \text {; başlangıç düzeyinde }=2 \text {; } \\
\text { normal düzeyde=3; ileri düzeyde }=4)\end{array}$ & 1,0548 & 0,32298 \\
\hline$B Y N D M R$ & $\begin{array}{l}\text { Beyin damar hastalığ1 (hayır=1; başlangıç düzeyinde }=2 \text {; } \\
\text { normal düzeyde=3; ileri düzeyde=4) }\end{array}$ & 1,0548 & 0,33880 \\
\hline$S \breve{G} L K B S N$ & $\begin{array}{l}\text { Sağlıklı besinler tüketmeye çalışma }(\text { hiç }=1 ; \text { çok } \\
\text { nadir }=2 ; \text { bazen }=3 ; \text { sık sık=4; daima }=5)\end{array}$ & 3,6736 & 1,20666 \\
\hline DKTRUYR & $\begin{array}{l}\text { Doktorun yapmış olduğu uyarıları dikkate alma }(\mathrm{hiç=1;} \\
\text { çok nadir }=2 ; \text { bazen }=3 ; \text { sık sık }=4 \text {; daima }=5)\end{array}$ & 4,0078 & 1,30943 \\
\hline
\end{tabular}

Araştırılan modellerin uyum iyiliğini değerlendirmek için sıklıkla modelin ya da parametrelerin anlamlılı̆̆ını test etmek için kullanılan Omnibus, Wald ve HosmerLemeshow testleri, doğru sınıflama oranları gibi yöntemler kullanılmaktadır. Bu çalışmada da bahsedilen test ve istatistikler kullanılmıştır (Oktay ve Orçanlı, 2014: 77-78). Tablo 12'de Omnibus Testine göre modelin 0,01 önem düzeyinde anlamlı olduğu görülmektedir.

Tablo 12. Model Katsayılarının Omnibus Testleri

\begin{tabular}{lccc}
\hline & Ki-kare $\left(\boldsymbol{x}^{\mathbf{2}}\right)$ & Serbestlik derecesi (df) & Önem düzeyi (p) \\
\hline Step & 92,019 & 8 & 0,000 \\
Block & 92,019 & 8 & 0,000 \\
Model & 92,019 & 8 & 0,000 \\
\hline
\end{tabular}

Modelin uyum iyiliğinin test edilmesinde kullanılan diğer yöntem ise Tablo 13'de yer alan sinıflandırma tablosunda gösterilmektedir. 
Tablo 13. Modelin Sinıflandırma Tablosu

Gözlenen

\begin{tabular}{ccc}
\multicolumn{3}{c}{ Beklenen } \\
\cline { 1 - 2 } $\begin{array}{c}\text { Özel Sağlık Sigortası } \\
\text { Sahipliği }\end{array}$ & $\begin{array}{c}\text { Doğruluk } \\
\text { Yüzdesi }\end{array}$ \\
\cline { 1 - 2 } Hayır & Evet & 97,9 \\
330 & 7 & 32,6 \\
\hline 31 & 15 & 90,1 \\
\hline
\end{tabular}

Tabloya göre; özel sağlık sigortasına sahip olmamayı doğru olarak tahmin etme oranı \%97,9 özel sağlık sigortasına sahip olmayı doğru tahmin etme oranı ise \%32,6 olarak elde edilmiştir. Modelde doğru sınıflandırma yapma oranının \%90,1 olduğu görülmektedir.

Modelin uyum iyiliğini değerlendirmek için Sınıflandırma Tablosu ve modelin anlamlılığının sınanmasında kullanılan Omnibus testi haricinde diğer yöntem ise Hosmer-Lemeshow Testidir. Hosmer-Lemeshow test istatistiği Tablo 14'de, test istatistiğini hesaplamak için gereksinim duyulan gözlenen ve beklenen frekanslar Tablo 15'de yer almaktadır.

Hosmer-Lemeshow test istatistiği, lojistik regresyon modelini test etmekte kullanılan önemli bir ölçüm metodudur. Bu istatistik, sabit terimin dışındaki tüm logit katsayılarının sıfıra eşit olup olmadı̆̆ını test eder.

" $H_{0}$ " hipotezi altında Hosmer-Lemeshow test istatistiğine ilişkin Ki-kare değerleri hesaplanmış ve Tablo 14'de verilmiştir. Bu teste yönelik hipotezler ise aşağıdaki gibidir;

$\mathrm{H}_{0}$ : Parametreler belirleyicilik açısından ayrımcılığa sahip

$\mathrm{H}_{1}$ : Parametreler belirleyicilik açısından ayrımcılığa sahip değil

Tablo 14. Hosmer-Lemeshow Testi

\begin{tabular}{lccc}
\hline Yöntem & Ki-Kare $\left(\boldsymbol{x}^{\mathbf{2}}\right)$ & Serbestlik derecesi (df) & Önem düzeyi (p) \\
\hline Hosmer-Lemeshow & 6,993 & 8 & 0,537 \\
\hline
\end{tabular}

Sonuçlara göre $\mathrm{H}_{0}$ hipotezi reddedilememiştir; parametreler belirleyicilik açısından iyi bir ayırımcılığa sahiptir. Ayrıca Tablo 16'dan da takip edileceği üzere gözlenen ve beklenen frekans değerleri arasında çok önemli farklılıkların olmadığı görülmektedir.

Tablo 15. Hosmer-Lemeshow Testi İçin Gözlenen ve Beklenen Frekanslar

\begin{tabular}{rccccc}
\hline & \multicolumn{2}{c}{ Özel Sağlık Sigortası = Hayır } & \multicolumn{2}{c}{ Özel Sağlık Sigortası = Evet } & \multirow{2}{*}{ Toplam } \\
\cline { 2 - 5 } & Gözlenen & Beklenen & Gözlenen & Beklenen & \\
\hline 1 & 38 & 37,952 & 0 &, 048 & 38 \\
\hline 2 & 38 & 37,770 & 0 &, 230 & 38 \\
\hline 3 & 38 & 37,536 & 0 &, 464 & 38 \\
\hline 5 & 37 & 37,265 & 1 & 1,735 & 38 \\
\hline 6 & 37 & 36,814 & 1 & 1,818 & 38 \\
\hline 7 & 38 & 36,182 & 0 & 2,974 & 38 \\
\hline 8 & 32 & 35,026 & 6 & 5,242 & 38 \\
\hline 10 & 34 & 32,758 & 4 & 10,241 & 38 \\
\hline
\end{tabular}


Lojistik Regresyon Model'inin özel sağlık sigortası satın alan ve özel sağlık sigortası satın almayan bireyleri gruplandırmada kullanılabilir bir model olduğu söylenebilir

Ortaya atılan bir modelin istatistiki açıdan değerlendirilip sonuçlarının yorumlanması önemlidir. Yapılan analizler sonucunda çalışmaların doğruluk payını ölçebilmek için özenli bir teste tabi tutulmadan elde edilen sonuçlar ışığında politikalar uygulanması doğru değildir. Analizde eksik kalan bazı şeyleri test istatistiklerinin ölçümü sonrası ortaya konulabilmektedir. Bunun içinde yapılan analizleri test etmek için birçok test tekniği geliştirilmiştir.

$\mathrm{R}^{2}$ bağımsız değişkenlerin bağımlı değişkenleri açıklama gücünü gösterir. Yapılan çalışmada Cox ve Snell $\mathrm{R}^{2}$ istatistiği yaklaşık olarak \%21,5'dir. Bu oran, modeldeki bağımsız değişkenlerin bağımlı değişkendeki değişkenliğin \%21,5'lik bir kısmını açıkladığını gösterir.

Tablo 16. Modelin $R^{2}$ Tablosu

\begin{tabular}{cccc}
\hline Step & -2 Log likelihood & Cox \& Snell R Square & Nagelkerke R Square \\
\hline 1 & 189,205 & 0,214 & 0,411 \\
\hline
\end{tabular}

Nagelkerke $\mathrm{R}^{2}$ istatistiği ise Cox ve Snell $\mathrm{R}^{2}$ istatistiğinin 0-1 aralığında değerler almasını sağlamak amacıyla geliştirilmiş bir ilişki test ölçüm metodudur (Kalayc1, 2010: 293).

Buna göre de, modeldeki bağımsız değişkenlerin bağımlı değişkendeki değişkenliğin $\% 41,1$ 'ini açıklamaktadır.

Araştırma bölgesinde yaşayan 45 yaş üstü kişilerin özel sağlık sigortası sahipliğini belirleyen demografik özelikleri, sosyoekonomik faktörler ve alışkanlıkları araştırılmış ve sonuçlar Tablo 17'de verilmiştir.

Tablo 17. İkili Lojistik Regresyon Analizi Sonuçları

\begin{tabular}{|c|c|c|c|c|c|c|}
\hline Değişkenler & Katsayı & $\begin{array}{c}\text { Standart } \\
\text { Hata }\end{array}$ & $\begin{array}{l}\text { Wald } \\
\text { Testi }\end{array}$ & $\begin{array}{c}\text { Serbestlik } \\
\text { Derecesi }\end{array}$ & $\begin{array}{c}\text { Önem } \\
\text { Düzeyi }\end{array}$ & $\begin{array}{l}\text { Bahis } \\
\text { Oranı }\end{array}$ \\
\hline$K R C \breve{G} R$ & 0,773 & 0,365 & 4,503 & 1 & 0,034 & 2,167 \\
\hline$B Y N D M R$ & 0,952 & 0,401 & 5,629 & 1 & 0,018 & 2,590 \\
\hline$S \breve{G} L K L B S N$ & $-0,291$ & 0,176 & 2,731 & 1 & 0,098 & 0,747 \\
\hline DKTRUYR & 0,401 & 0,192 & 4,338 & 1 & 0,004 & 1,493 \\
\hline$Y A S$ & $-0,050$ & 0,024 & 4,401 & 1 & 0,036 & 0,951 \\
\hline$G L R$ & 1,751 & 0,365 & 23,031 & 1 & 0,000 & 5,761 \\
\hline$E \breve{G} T M$ & 0,697 & 0,205 & 11,547 & 1 & 0,001 & 2,007 \\
\hline$S R V T$ & 0,671 & 0,194 & 11,955 & 1 & 0,001 & 1,956 \\
\hline Sabit & $-10,254$ & 2,169 & 22,351 & 1 & 0,000 & 0,000 \\
\hline
\end{tabular}

Tablo 17'deki lojistik regresyon sonuçlarına göre İstanbul ili özel sağlık sigortası yaptırmada ön plana çıkan faktörlerin bireysel anlamlılıklarına bakıldığında, GLR, EĞTM, DKTRYPMŞ ve $S R V T \% 1 ; \quad K R C \breve{G} R, B Y N D M R$ ve $Y A S ̧ \% 5 ; \quad S \breve{G} L K B S N$ ise \%10 önem düzeyinde istatistiksel olarak anlamlı bulunmuştur. 
Karaciğer hastalığı olma (KRCĞR) değişkeninin katsayı işareti pozitif ve anlamlı olup, değişkene ait 2,167 olarak bulunan bahis (odds) oranı, diğer şartlar sabitken karaciğer hastalığı olan bireylerin olmayanlara göre özel sağlık sigortası yaptırma olasılığını 2,167 kat artıracaklarını ifade eder. Bu değişkenin işaretinin pozitif olması kişilerin tehlikeli bir hastalık olan karaciğer hastalığına karşı daha kaliteli bir hizmet alarak sağlıklarına tekrar kavuşmayı istedikleri şeklinde yorumlanabilir.

Beyin-damar hastalığı olma (BYNDMR) değişkeninin katsayı işareti pozitif olup, beyindamar hastası olan bireyin beyin-damar hastası olmayana göre özel sağlık sigortası yaptırma olasılığı 2,590 kat fazladır.

Sağlıklı beslenme ( $\breve{G} L K B S N)$ değişkeninin katsayı işareti negatif bulunmuş olup, sağlıklı beslenen bir bireyin sağlıklı beslenmeyene göre özel sağlık sigortası yaptırma olasılığı 1,33 $(1 / 0,747)$ kat aratabilecektir. Bu değişkenin işaretinin negatif olması kendi sağlık durumlarına dikkat eden kişilerin özel sağlık sigortası poliçesi satın alma konusuna sıcak bakmadıklarını kendilerini koruduklarını düşündükleri söylenebilir.

Doktorun yapmış olduğu uyarılarını dikkate alma (DKTRUYR) değişkeninin katsayı işareti pozitif bulunmuş olup, doktorun uyarılarını dikkate alan bireyin almayanlara göre özel sağlık sigortası yaptırma olasılığı 1,493 kat fazladır. Bu değişkenin işaretinin pozitif çıkması kendi sağlık durumlarını titizlikle koruyan kişilerin doktorun söyleyeceği uyarıları dikkate alarak sağlık durumlarını daha iyi seviyeye getirmek için özel sağlık sigortası poliçesini satın alabileceklerini göstermektedir.

$Y A S ̧$ değişkenine ait olan 0,951 bahis oranının anlamı kişilerin yaşları ilerledikçe özel sağlık sigortası yaptırma olasılıklarının da $1,05(1 / 0,951)$ kat azalacağını ifade eder.

Gelir (GLR) değişkenine ait olan 5,761 bahis oranının anlamı kişilerin gelirleri arttıkça özel sağlık sigortası yaptırma olasılıkları 5,761 kat artacaktır. Beklendiği gibi katılımcıların gelirlerinde meydana gelecek olan artış özel sağlık sigortası poliçesi satın almalarını olumlu yönde etkilemektedir.

Eğitim (E $\breve{G T M)}$ değişkenine ait olan 2,007 bahis oranının anlamı ise kişilerin eğitim seviyesi arttıkça özel sağlık sigortası yaptırma olasılıklarının 2,007 kat artabileceğini ifade eder. Bu değişkenin işaretinin pozitif olması da beklendiği gibi katılımcıların eğitim düzeyleri yükseldikçe kendi sağlıklarını önemsediklerini ve karşılaştıkları hastalıklar karşısında daha kaliteli bir yaşam için özel sağlık sigortası poliçesi satın alabileceklerini göstermektedir.

Servet $(S R V T)$ değişkenine ait olan 1,956 bahis oranının anlamı kişilerin servetlerin de meydana gelebilecek artışın özel sağlık sigortası yaptırma olasılıklarını 1,956 kat artırabileceklerini ifade eder. Bu değişkenin işaretinin pozitif çıkmasının anlamı, toplam mal varlığı yüksek olan kişilerin kendi sağlık durumlarını korumak için daha kaliteli hizmetten faydalanabileceklerdir. 


\section{SONUÇ}

Türkiye'de özel sağlık sigortası branşı gelişme gösteren bir sigorta türüdür. Özel sağlık sigortası insanların hayatları boyunca karşılaşabilecekleri hastalıklara karşı önlem almak istemelerinden dolayı doğmuş bir sigorta türüdür. Zaman içinde gelişme gösteren özel sağlık sigortası gerek yurt içi gerek yurt dışında yaşayan insanlar için cazip hale getirilmelidir.

Sigortacılık faaliyetlerinin Türkiye'de ülke ekonomisine katkısına bakıldığında sigorta sektörünün yıllar itibariyle yapmıș olduğu katkılar göz ardı edilemeyecek kadar önemli boyuttadır. Türkiye gibi gelişmekte olan ülkelerde, sigorta sektörü hakkında tüketicilerin bilinçlenmesi ile sigorta sektörünün ekonomi içindeki rolü artırılabilir. Devletin yapacağı destek projeleri ile sigortacılık sektörü geliştirilebilir. Sigorta sektörünün fon yaratıcı, döviz kazandırıcı ve istikrarı artırıcı etkileri de göz önünde bulundurarak, sigorta sektörüne hak ettiği değer verilmelidir. Türk sigorta pazarı Avrupa'da en hızlı büyüyen sektörler arasında yer almaktadır.

Bu çalışma ile de İstanbul ili 45 yaş üstü kişilerin özel sağlık sigortası yaptırması üzerinde etkili olan faktörlerin belirlenmesi amaçlanmıştır. $\mathrm{Bu}$ amaçla, hazırlanan anket formu İstanbul ili 45 yaşın üzerinde olan kişilere uygulanmıştır. Özel sağlık sigortası yaptırmayı etkileyen faktörler, logit regresyon modeli ile analiz edilmiştir. Regresyon analizine birçok faktör dâhil edilmiş, birçok denemeden sonra en uygun model belirlenmiştir. İstanbul ili kentsel alanda yapılan çalışmada özel sağlık sigortası tercihinde ön plana çıkan Karaciğer hastalığı, beyin damar hastalığı, sağlıklı besinler tüketmeye çalışma, doktorun yapmış olduğu uyarınlar dikkate alma, yaş değişkeni, aylık ortalama gelir, eğitim düzeyi ve servet durumu değişkenleri istatistiksel olarak anlamlı bulunmuştur. Elde edilen bulgulardan, 45 yaşın üzerinde olan kişilerin özel sağlık sigortası tercihinde bazı hastalık türlerine sahip olmaları, alışkanlıkları, sosyoekonomik ve demografik faktörlerin göz ardı edilmeyecek kadar önemli oldukları söylenebilir. Sigorta şirketlerinin planlamalarını yaparken yukarıdaki faktörleri dikkate almaları lehlerine olabilecektir.

Çalışmanın uygulama aşamasında gözlemlenen en önemli bulgulardan birisi özel sağlık sigortasının tüketiciler açısından tam olarak anlaşılmadığı kişilerin bu konuda tam bir bilgiye sahip olmadığıdır. Sigorta sektörünün kişiler açısından ne anlama geldiği neleri kapsadığı, sigortanın konusu gibi sigortayı açıklayıcı özellikler konusunda kişiler bilinçsiz durumdadır. Yapılacak çalışmalar kişilerdeki sigorta bilincini artırmaya yönelik kurgulanabilir. Sigorta şirketleri, reklam kampanyalarını artırabilir, kişilerin danışabilecekleri, merak ettikleri konular hakkında bilgi edinebilecekleri iletişim merkezleri müşteri hizmet servisleri kurabilir. Özel sağlık sigortası hizmeti kişiler tarafından anlaşılır hale geldiğinde, bu hizmetten yararlanmak isteyecek olan insanların sayısı artabilecektir.

Sigorta sektörünün gelişimi ülke ekonomisi içinde büyük önem arz etmektedir. Bu durum göz önüne alınarak devletinde de konuyla ilgili yasal düzenlemeler ve özendirme politikaları geliştirmelidir.

Özel sağlık sigortası hizmetini sunan bu şirketler müşterilerini memnun etmek için neler yapabileceklerini tekrar gözden geçirmeli ve ona göre bir düzenlemeye gitmelidir.

Gelişen çağın gereklerine göre sigorta artık her birey için zorunluluk haline gelme aşamasındadır. Konu sağlık olduğunda ise bu durum daha ciddi bir hâl almaktadır. Fakat analiz sonucuna göre göz ardı edilemeyecek değişkenlerden biri de gelirdir. İnsanların gelir düzeyleri arttığında özel sağlık sigortası satın alma istekleri de artmaktadır. Geliri düşük veya orta düzeyde olan kişilerinde özel sağlı sigortasını tercih etmeleri için şirketler poliçe fiyatlarını düzenleyebilir. Kişilerin özel hastalık durumlarına göre farklılık gösteren poliçeler sunabilirler. Sigorta sektöründeki şirketler yapılan analizleri dikkate aldıklarında karlılık oranlarını yükseltebileceklerdir. 


\section{Kaynakça}

Akay, H. (2001). Hayat Sigorta Sirketlerinde Hesap Isşleri Düzeni. İstanbul: Türkmen Kitabevi.

Akmut, Ö. (1980). Hayat Sigortasi Teori ve Türkiye'de Uygulama. Ankara: Ankara Üniversitesi Siyasal Bilgiler Fakültesi Yayınları.

Aktuğlu, M. A. (1984). Sigorta Muhasebesi. İzmir: Dokuz Eylül Üniversitesi Yayınları.

Arık Ö. (2010). Avrupa Birliğine Giriş Sürecinde Türkiye'de Özel Sağllk Sigortalarının Durumu ve Avrupa Birliği'ndeki Özel Sağllk Sigortası Uygulamaları ile Bir Karşılaştırma. (Yayınlanmamış Yüksek Lisans Tezi). Adana: Çukurova Üniversitesi Sosyal Bilimler Enstitüsü.

Asunakutlu, T. (1997). Sigorta İşletmelerinde Yatırım Yaklaşımları: Alternatif Modeller ve Türkiye Uygulaması. (Yayınlanmamış Doktora Tezi). İzmir: Dokuz Eylül Üniversitesi Sosyal Bilimler Enstitüsü.

Avşar N. (2010). Türkiye'de Özel Sağllk Sigortası ve Sağllk Sistemi. (Yayınlanmamış Yüksek Lisans Tezi). Beykent Üniversitesi Sosyal Bilimler Enstitüsü. İstanbul.

Bölükbaşı, A. ve Pamukçu, G. B. (2009). Sigortanin Temel Prensipleri. İstanbul: Türkmen Kitapevi.

Coşkun, S., Kartal, M., Coşkun, A. ve Bircan, H. (2004). Lojistik Regresyon Analizinin İncelenmesi ve Diş Hekimliğinde Bir Uygulaması. Cumhuriyet Üniversitesi Diş Hekimliği Fakültesi Dergisi. 7(1). 41-50.

Çaldağ, Y. (1982). Hayat Sigortası Ortaklıklarında Sigorta Isslemleri ve Muhasebe Denetimi. Ankara İktisadi Ticari İlimler Akademisi. Ankara.

Duman, G. Ş. (1983). Türk Sigorta Sektöründe Üretim Faaliyetleri ve Ekonomik Kayıpları. İ. Ü. Sosyal Bilimler Enstitüsü. [https://katalog.marmara.edu.tr/eyayin/tez/ T0039980.pdf]. (Erişim: 10 Temmuz 2019).

Elveren, A. H. (1994). Türkiye'de Hayat Sigortalarl: Yapısl, Sorunlar ve Çözüm Önerileri. (T.C. Başbakanlık Hazine ve Dış Ticaret Müsteşarlığ 1 Uzmanlık Tezi). Ankara.

Filiz Y. (2010). Ekonomik Büyüme ve Sağllk Harcamaları İlişkisi. (Yayınlanmamış Yüksek Lisans Tezi ). Atılım Üniversitesi Sosyal Bilimler Enstitüsü. Ankara.
Güvel, E. A. ve Güvel, A. Ö. (2002). Sigortacılık. Ankara: Seçkin Yayınevi.

Kalayc1, Ş. (2010). SPSS Uygulamalı Çok Değişkenli İstatistik Teknikleri. Ankara: Asil Yayın Dağıtım.

Keçeci, G. (2002). Özgün Bir Sigorta Sektörü Olarak Hayat Sigortacılığl ve Türkiye'deki Gelişiminin Analizi ve Eğitim Süreci. (Yayınlanmamış Yüksek Lisans Tezi). Gazi Üniversitesi Eğitim Bilimleri Enstitüsü. Ankara.

Oktay, E. ve Orçanlı, K. (2014). Atatürk Üniversitesinde İnternet Bankacılığının Kullanımını Etkileyen Faktörlerin Belirlenmesi. Uludağ Üniversitesi Sosyal Bilimler Dergisi. (18). 57-91.

Lee, Y.W. (2012). Asymmetric Information and the Demand for Private Health Insurance in Korea. Economics Letters. 116.(2012). 284-287.

Orhaner, E. (2000). Türkiye'de Sağllk Sigortası. Ankara: Gazi Kitapevi.

Osmançavuşoğlu, Ö. (1999). Hayat Sigortalarında Aktüerya. T.C. Başbakanlık Hazine Müsteşarlığı Uzmanlık Tezi. Ankara.

Sağlam, N. (1996). Sigorta İşletmelerinde Mali Tabloların Hazırlanmasi ve Avrupa Birliği'ne Uуuтu. (Yayınlanmamış Doktora Tezi). Anadolu Üniversitesi Sosyal Bilimler Enstitüsü. Eskişehir.

Tıraş H. H. (2013). Sağlık Ekonomisi: Teorik Bir İnceleme. Kahramanmaraş Sütçü İmam Üniversitesi İktisadi ve İdari Bilimler Fakültesi Dergisi. 9(1). 125-152.

Tiryaki D., Tatar M. (2000). Sağlık Sigortası: Teori ve Uygulama. H.Ü. Hacettepe Sağllk İdaresi Dergisi. 5(4). 126-128.

Uğur, S. (2004). Sosyal Güvenlik Sistemlerinde Özel Emeklilik Programlarının Yeri ve Gelişimi. Ankara: Türkiye İşveren Sendikaları Konfederasyonu Yayınları.

Yaman, Y. S. (2001). Türk Sigorta Sektörünün Sorunlarl ve Eğitimin Önemi. (Yayınlanmamış Yüksek Lisans Tezi). Marmara Üniversitesi Bankacılık ve Sigortacılık Enstitüsü. İstanbul.

Yayar, R., Çoban, M. N. ve Tekin, B. (2015). Otomobil Sahipliğini Etkileyen Faktörlerin Belirlenmesi: Tokat İli Kentsel Alanda Bir Uygulama. C.B.Ü. Yönetim ve Ekonomi Dergisi. 22(2). 608-609. 
Türkiye Sigorta Birliği (2018). [http://tsrsb.org.tr/ sayfa/sigortanın-tarihi]. (Erişisim: 25 Ocak 2018).

Türkiye Sigorta Birliği (2018). [http://tsrsb.org.tr/sayfa/turkiyede-sigortacilik]. (Erişim: 27 Ocak 2018).

Türkiye Sigorta Birliği 2011 Y1lı Faaliyet Raporu (2012). [https://www.tsb.org. tr/Document / Yayinlar / 2011\%20Y\%C4\%B11\%C4\%B1\%20Faaliyet\%2 0Raporu.pdf]. (Erişim: 30 Temmuz 2019).

Türkiye Sigorta Birliği 2012 Y1lı Faaliyet Raporu (2013). [https://www.tsb.org.tr/ Document/Yayinlar/2012 \%20Y\%C4 \%B1l \%C4 \%B1\%20Faaliyet\%20Raporu.pdf]. (Erişim: 30 Temmuz 2019).

Türkiye Sigorta Birliği 2013 Y1lı Faaliyet Raporu (2014). [https://www.tsb.org.tr/ Document/Yayinlar/2013\%20Y \%C4 \%B11\% C4\%B1 \%20Faaliyet\%20Raporu.pdf]. (Erişim: 30.07.2019).

Türkiye Sigorta Birliği 2014 Y1lı Faaliyet Raporu (2015). [https://www.tsb.org.tr/ Document/Yayinlar/2014\%20Y \%C4 \%B1l \%C4\%B1 \%20Faaliyet\%20Raporu.pdf]. (Erişim: 30.07.2019).

Türkiye Sigorta Birliği 2015 Y1lı Sektör Raporu (2016). [https://www.tsb.org.tr/ Document/ Yayinlar/2015\%20Y\%C4\%B11\%C4\%B1\%20S ekt\%C3\%B6r\%20Raporu\%20T\%C3\%BCrk\%C 3\%A7e.pdf]. (Erişim: 30 Temmuz 2019).

Türkiye Sigorta Birliği 2016 Y1lı Sektör Raporu. (2017). [https://www.tsb.org.tr/ Document/ Yayinlar/2016\%20Y\%C4\%B11\%C4\%B1\%20S ekt\%C3\%B6r\%20Raporu\%20T\%C3\%BCrk\%C 3\%A7e.PDF]. (Erişim: 30 Temmuz 2019).

Akay, H. (2001). Hayat Sigorta Şirketlerinde Hesap Isşleri Düzeni. İstanbul: Türkmen Kitabevi.

Akmut, Ö. (1980). Hayat Sigortast Teori ve Türkiye'de Uygulama. Ankara: Ankara Üniversitesi Siyasal Bilgiler Fakültesi Yayınları.

Aktuğlu, M. A. (1984). Sigorta Muhasebesi. İzmir: Dokuz Eylül Üniversitesi Yayınları.

Arık Ö. (2010). Avrupa Birliğine Giriş Sürecinde Türkiye'de Özel Sağlık Sigortalarının Durumu ve Avrupa Birliği'ndeki Özel Sağlık Sigortası Uygulamaları ile Bir Karşılaştırma. (Yayınlanmamış Yüksek Lisans Tezi). Adana: Çukurova Üniversitesi Sosyal Bilimler Enstitüsü.
Asunakutlu, T. (1997). Sigorta Ișsletmelerinde Yatırım Yaklaşımlart: Alternatif Modeller ve Türkiye Uygulaması. (Yayınlanmamıș Doktora Tezi). İzmir: Dokuz Eylül Üniversitesi Sosyal Bilimler Enstitüsü.

Avşar N. (2010). Türkiye' de Özel Să̆lık Sigortası ve Sağlık Sistemi. (Yayınlanmamış Yüksek Lisans Tezi). Beykent Üniversitesi Sosyal Bilimler Enstitüsü. İstanbul.

Bölükbaşı, A. ve Pamukçu, G. B. (2009). Sigortanin Temel Prensipleri. İstanbul: Türkmen Kitapevi.

Coşkun, S., Kartal, M., Coşkun, A. ve Bircan, H. (2004). Lojistik Regresyon Analizinin İncelenmesi ve Diş Hekimliğinde Bir Uygulaması. Cumhuriyet Üniversitesi Diş Hekimliği Fakültesi Dergisi. 7(1). 41-50.

Çaldağ, Y. (1982). Hayat Sigortası Ortaklıklarında Sigorta İşlemleri ve Muhasebe Denetimi. Ankara İktisadi Ticari İlimler Akademisi. Ankara.

Duman, G. Ş. (1983). Türk Sigorta Sektöründe Üretim Faaliyetleri ve Ekonomik Kayıpları. İ. Ü. Sosyal Bilimler Enstitüsü. [https://katalog. marmara.edu.tr/eyayin/tez/T0039980.pdf]. (Erişim: 10 Temmuz 2019).

Elveren, A. H. (1994). Türkiye'de Hayat Sigortaları: Yapısı, Sorunlar ve Çözüm Önerileri. (T.C. Başbakanlık Hazine ve Dış Ticaret Müsteşarlığı Uzmanlık Tezi). Ankara.

Filiz Y. (2010). Ekonomik Büyüme ve Să̆lık Harcamaları İlişkisi. (Yayınlanmamış Yüksek Lisans Tezi ). Atılım Üniversitesi Sosyal Bilimler Enstitüsü. Ankara.

Güvel, E. A. ve Güvel, A. Ö. (2002). Sigortacılık. Ankara: Seçkin Yayınevi.

Kalaycı, Ş. (2010). SPSS Uygulamalı Çok Değişkenli Istatistik Teknikleri. Ankara: Asil Yayın Dağıtım.

Keçeci, G. (2002). Özgün Bir Sigorta Sektörü Olarak Hayat Sigortacıliğg ve Türkiye'deki Gelişiminin Analizi ve Eğitim Süreci. (Yayınlanmamış Yüksek Lisans Tezi). Gazi Üniversitesi Eğitim Bilimleri Enstitüsü. Ankara.

Oktay, E. ve Orçanlı, K. (2014). Atatürk Üniversitesinde İnternet Bankacılığının Kullanımını Etkileyen Faktörlerin Belirlenmesi. Uludă̆ Üniversitesi Sosyal Bilimler Dergisi. (18). 57-91. 
Lee, Y.W. (2012). Asymmetric Information and the Demand for Private Health Insurance in Korea. Economics Letters. 116.(2012). 284-287.

Orhaner, E. (2000). Türkiye'de Sağlık Sigortast. Ankara: Gazi Kitapevi.

Osmançavuşoğlu, Ö. (1999). Hayat Sigortalarında Aktüerya. T.C. Başbakanlık Hazine Müsteşarlığı Uzmanlık Tezi. Ankara.

Sağlam, N. (1996). Sigorta İşletmelerinde Mali Tabloların Hazırlanması ve Avrupa Birliği'ne Uуuтu. (Yayınlanmamış Doktora Tezi). Anadolu Üniversitesi Sosyal Bilimler Enstitüsü. Eskişehir.

Tiraş H. H. (2013). Sağlik Ekonomisi: Teorik Bir İnceleme. Kahramanmaraş Sütçü Imam Üniversitesi İktisadi ve İdari Bilimler Fakültesi Dergisi. 9(1). 125-152.

Tiryaki D., Tatar M. (2000). Sağlık Sigortas1: Teori ve Uygulama. H.Ü. Hacettepe Sağllk İdaresi Dergisi. 5(4). 126-128.

Uğur, S. (2004). Sosyal Güvenlik Sistemlerinde Özel Emeklilik Programlarının Yeri ve Gelişimi. Ankara: Türkiye İşveren Sendikaları Konfederasyonu Yayınları.

Yaman, Y. S. (2001). Türk Sigorta Sektörünün Sorunlarl ve Ë̆itimin Önemi. (Yayınlanmamış Yüksek Lisans Tezi). Marmara Üniversitesi Bankacılık ve Sigortacılık Enstitüsü. İstanbul.

Yayar, R., Çoban, M. N. ve Tekin, B. (2015). Otomobil Sahipliğini Etkileyen Faktörlerin Belirlenmesi: Tokat İli Kentsel Alanda Bir Uygulama. C.B.Ü. Yönetim ve Ekonomi Dergisi. 22(2). 608-609.

Türkiye Sigorta Birliği (2018). [http://tsrsb.org.tr/ sayfa/sigortanın-tarihi]. (Erişim: 25 Ocak 2018).

Türkiye Sigorta Birliği (2018). [http://tsrsb.org.tr/sayfa/turkiyede-sigortacilik]. (Erişim: 27 Ocak 2018).

Türkiye Sigorta Birliği 2011 Y1lı Faaliyet Raporu (2012). [https://www.tsb.org. tr/Document / Yayinlar / 2011\%20Y\%C4\%B11\%C4\%B1\%20Faaliyet\%2 0Raporu.pdf]. (Erişim: 30 Temmuz 2019).

Türkiye Sigorta Birliği 2012 Y1lı Faaliyet Raporu (2013). [https://www.tsb.org.tr/ Document/Yayinlar/2012 \%20Y\%C4 \%B1l \%C4 \%B1\%20Faaliyet\%20Raporu.pdf]. (Erişim: 30 Temmuz 2019).
Türkiye Sigorta Birliği 2013 Y1lı Faaliyet Raporu (2014). [https://www.tsb.org.tr/ Document/Yayinlar/2013\%20Y \%C4 \%B1l\% C4\%B1 \%20Faaliyet\%20Raporu.pdf]. (Erişim: 30.07.2019).

Türkiye Sigorta Birliği 2014 Y1lı Faaliyet Raporu (2015). [https://www.tsb.org.tr/ Document/Yayinlar/2014\%20Y \%C4 \%B1l \%C4\%B1 \%20Faaliyet\%20Raporu.pdf]. (Erişim: 30.07.2019).

Türkiye Sigorta Birliği 2015 Y1lı Sektör Raporu (2016). [https://www.tsb.org.tr/ Document/ Yayinlar/2015\%20Y\%C4\%B1l\%C4\%B1\%20S ekt\%C3\%B6r\%20Raporu\%20T\%C3\%BCrk\%C 3\%A7e.pdf]. (Erişim: 30 Temmuz 2019).

Türkiye Sigorta Birliği 2016 Y1lı Sektör Raporu (2017). [https://www.tsb.org.tr/ Document/ Yayinlar/2016\%20Y\%C4\%B11\%C4\%B1\%20S ekt\%C3\%B6r\%20Raporu\%20T\%C3\%BCrk\%C 3\%A7e.PDF]. (Erişim: 30 Temmuz 2019). 